\title{
41. RIFTING OF THE GALICIA MARGIN: CRUSTAL THINNING AND EMPLACEMENT OF MANTLE ROCKS ON THE SEAFLOOR ${ }^{1}$
}

\author{
Gilbert Boillot, Laboratoire de Géodynamique Sous-Marine du CEROV, Villefranche-sur-Mer, France \\ Jacques Girardeau, Laboratoire de Pétrologie Physique, Université de Paris VII et IPGP, Paris, France \\ and \\ Jacques Kornprobst, Centre de Recherches Volcanologiques, U. A. no. 10, Clermont-Ferrand, France
}

\begin{abstract}
Thinning of the continental crust beneath the western Galicia margin during rifting was associated with the emplacement of mantle-derived peridotite at the ocean/continent boundary. Constraints that must be considered in models of this rifting are (1) the delay of block tilting relative to the deepening and subsidence of the margin (i.e, crustal thinning); (2) the discrepancy between the amount of superficial distension and the amount of crustal thinning, with distension less than thinning; (3) the probability that thinning of the crust occurred mainly at the expense of its lower part; (4) the partial melting of the peridotite at high temperature $\left(1250^{\circ}-970^{\circ} \mathrm{C}\right)$ during the first stage of uplift and its subsequent behavior in a similar manner as the asthenosphere; and (5) the mylonitization of the peridotite at decreasing temperature $\left(1000^{\circ}-\right.$ $\left.850^{\circ} \mathrm{C}\right)$ and depth $(30-7 \mathrm{~km})$ in a simple-shear regime. These constraints point to models combining heterogeneous stretching of the lithosphere, gliding along detachment faults, and asthenosphere diapirism.

Tectonic denudation of upper mantle by normal shear of the lithosphere accounts for the processes of crustal thinning and the brittle deformation and ultimate emplacement of the serpentinized peridotite on the seafloor. On the other hand, the asthenosphere diapirism model is in agreement with the physical conditions inferred for the melting and ductile deformation of the peridotite. Therefore, we propose a composite model consisting of two stages: (1) asthenospheric upwelling of the peridotites beneath a poorly (if at all) thinned continental crust and (2) crustal thinning and tectonic denudation of the cooled, poorly depleted peridotite by movement along a gently dipping normal detachment fault rooted in the upper mantle. This composite model accounts for all the data currently available from the Galicia margin.
\end{abstract}

\section{INTRODUCTION}

Investigating rifting processes on a typical passive margin was the main scientific objective of Ocean Drilling Project (ODP) Leg 103 (Shipboard Scientific Party, 1987a). The data collected on Leg 103 advanced understanding of the timing of events, the tectonic response to the crustal extension, and the sedimentary record of the subsidence related to rifting of the margin. However, in our opinion, the most significant result confirms the emplacement of mantle rocks onto the seafloor at the continental rift axis, the existence of which had been suspected from the dredge sampling of serpentinized peridotite at the ocean/continent transition, $350 \mathrm{~km}$ to the west of the Galicia coast (Boillot et al., 1980). Results of drilling at Site 637 ("Site 637" chapter; Shipboard Scientific Party, 1987b) and diving on the deep margin (Boillot et al., 1986a, this volume) demonstrate that serpentinized peridotites form a continuous belt bounding the margin.

To account for the uplift of mantle rocks on the seafloor in relation to continental rifting, several distinct models have been proposed. These include diapiric emplacement (Nicolas et al., 1987; Bonatti, 1987) and tectonic denudation by detachment faulting (Boillot et al., 1987). However, progressive uplift and final emplacement of peridotites at the Earth's surface seem to be related to the thinning of the continental crust beneath the rift. For that reason, in this paper we consider both crustal thinning in space and time, as shown by geological and geophysical data, and the evidence for peridotite upwelling from petrological and structural studies. All data are consistent and strongly constrain models for the lithosphere-stretching process.

${ }^{1}$ Boillot, G., Winterer, E. L., et al., 1988. Proc. ODP, Sci. Results, 103: College Station, TX (Ocean Drilling Program).

\section{TECTONIC SETTING}

The western Galicia margin (Fig. 1) was described in detail by Montadert et al. (1974, 1979), Groupe Galice (1979), Boillot et al. (1979), and, more recently, by Mauffret and Montadert (1987), Sibuet et al. (1987), and Thommeret et al. (this volume). To the northwest of Galicia Bank, the margin was involved in the Pyrenean fold belt (Grimaud et al., 1982). Conversely, the area drilled by ODP Leg 103 (Fig. 2) was not affected by Eocene tectonics and, therefore, has retained all of the structural-and even morphological-Mesozoic features of the continental rift since activity ceased 115 Ma ago (Figs. 3 and 4). Tilted crustal blocks in the area of the margin drilled by Leg 103 are about 15 $\mathrm{km}$ wide, trend north-south, and are locally offset by northeastsouthwest transverse faults. To the west, the margin is bounded by the "peridotite" ridge (Fig. 2), at least $10 \mathrm{~km}$ wide and $130 \mathrm{~km}$ long, where serpentine has been sampled by dredging (Boillot et al., 1980), coring (Leg 103; Shipboard Scientific Party, 1987b), and diving (Galinaute cruise; Boillot et al., 1986a, this volume).

Regional magnetic anomalies include the M0 anomaly, which seems to terminate northward at $40^{\circ} 20^{\prime} \mathrm{N}$ (Fig. 1). To the west, anomaly A34-33 is well defined, and the Iberian Abyssal Plain bounding the western Galicia margin is probably floored by oceanic crust included in the Cretaceous quiet magnetic zone (see discussion in Verhoef et al., 1986). The peridotite ridge is inferred to mark the ocean/continent boundary.

On the Galicia margin, crustal rocks were sampled by dredging (Capdevila and Mougenot, this volume), coring (Evans and Girardeau, this volume), and diving (Boillot et al., this volume). The samples consist of granodiorites, gneisses, some granites and mica schists, and a few metasedimentary rocks. All of these rocks belong to the upper part of the continental crust. Except for two pebbles of uncertain origin, no samples of high-grade metamorphic rock (granulite facies) were recovered at the edge 


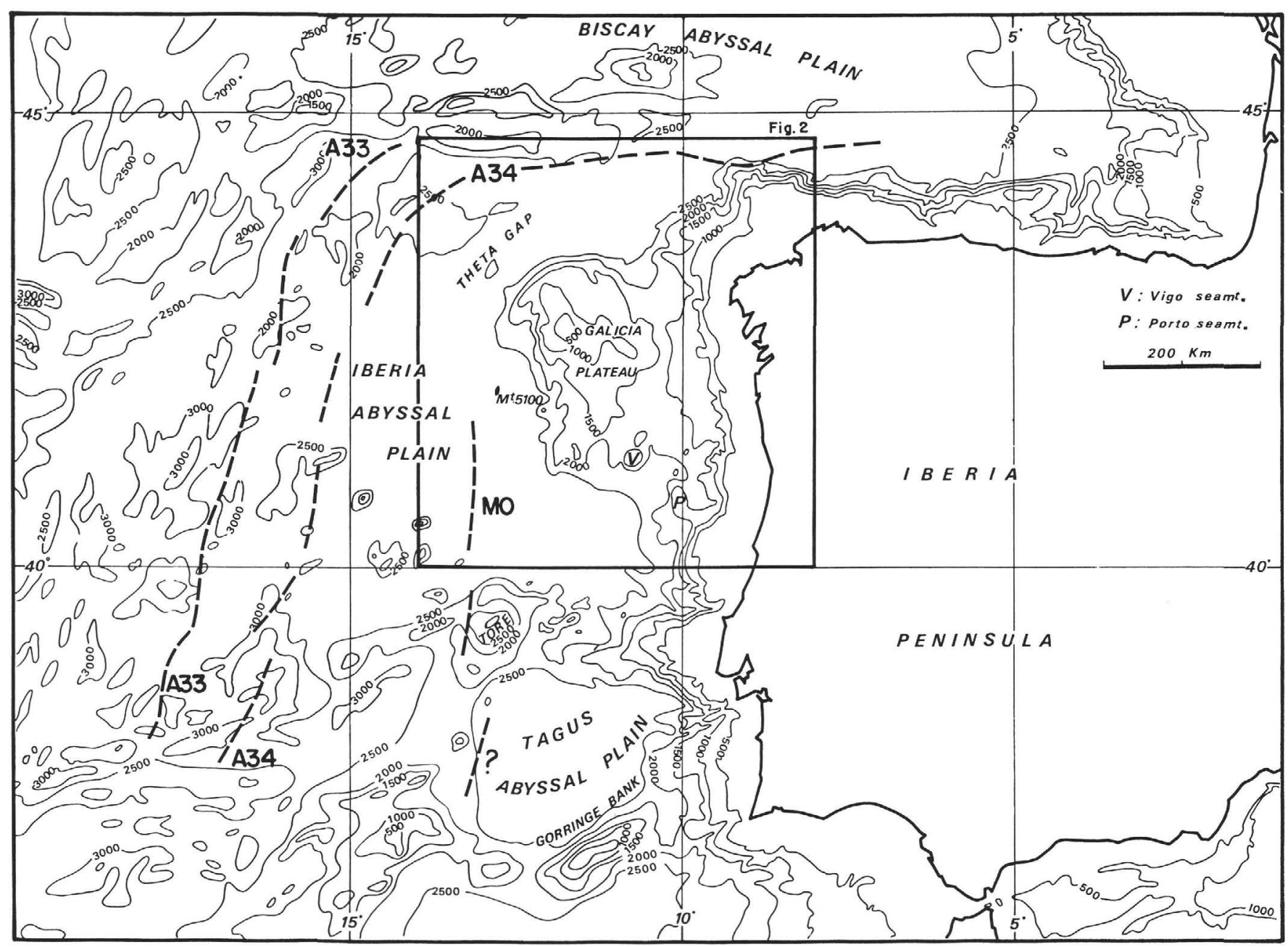

Figure 1. Location of the Galicia margin in the northeastern Atlantic. Magnetic anomalies after Guennoc et al. (1979), compiled by Mauffret and Montadert (1987). Bathymetry in fathoms, after Laughton et al. (1975). The location of Figure 2 is shown.

of the margin. Thus, we suspect that the lower crust is missing and that the upper continental crust directly overlies the peridotite at the ocean/continent boundary.

\section{THINNING AND DISTENSION OF THE CONTINENTAL CRUST}

In the following section, we focus on some peculiarities of the rifting process at the west Galicia margin. In particular, we compare the thinning coefficient, $\beta$, for the lithosphere (McKenzie, 1978) with the stretching coefficient, $e$, for the brittle crust (Chenet et al., 1982), and we also consider the delay between subsidence and tilting of the crustal blocks.

\section{Age of Crustal Thinning and Relationship Between Subsidence of the Margin and Tilting of the Crustal Blocks}

The history of western Galicia margin rifting can be constructed from investigations at Sites 638 and 639 (Fig. 2). In the Tithonian $(150 \mathrm{Ma})$, the present-day margin was occupied by a shallow-water platform that subsided slowly (Jansa et al., this volume; Moullade et al., this volume). At Site 639 , some $40 \mathrm{~m}$ of hemipelagic calpionellid marlstone of early Valanginan age (135 Ma) was deposited on the subsiding platform as water depth increased up to 600 or $1000 \mathrm{~m}$ (Moullade et al., this volume). Shortly afterward, during the middle to late Valanginian (132 Ma), the calcareous sediments were buried by coarse quart- zose-feldspathic turbidite sands. Microfossils are scarce in these strata, but the presence of resedimented foraminiferal species representing neritic to infrabathyal environments suggests accumulation in relatively deep water $(2000-3000 \mathrm{~m}$, after Moullade et al., this volume). Thus, the data from Leg 103 show that the Galicia margin began to deepen rapidly in the early Valanginian (135 Ma), as calpionellid marls and coarse clastics replaced platform sediments. This deepening was an isostatic response to thinning of the continental crust, that is, a result of the rifting of the margin that began in the Berriasian or in the earliest Valanginian (144-140 Ma).

Multichannel seismic-reflection profile GP-101 (Figs. 3 and 4) illustrates the successive stages of deposition of the drilled sequences. Above a strong reflector identified as the top of the Tithonian carbonate platform (Fig. 5B), the Valanginian-lower Hauterivian sandy turbidites form a relatively transparent seismic layer, tilted with the underlying carbonates and basement and showing a fairly uniform thickness from the summit of the tilted blocks traced into the half-grabens on the downthrown side of the blocks. This geometry, unexpected in a syn-rift sequence, was what led to an error in interpretation of the seismic profiles prior to Leg 103; the transparent layer, tilted with the basement, was originally interpreted as a sequence of pre-rift sediments of Late Jurassic age. The results of drilling now enable correction of this misinterpretation, but the deposition of detrital Valanginian sediment in fairly deep water prior to the 


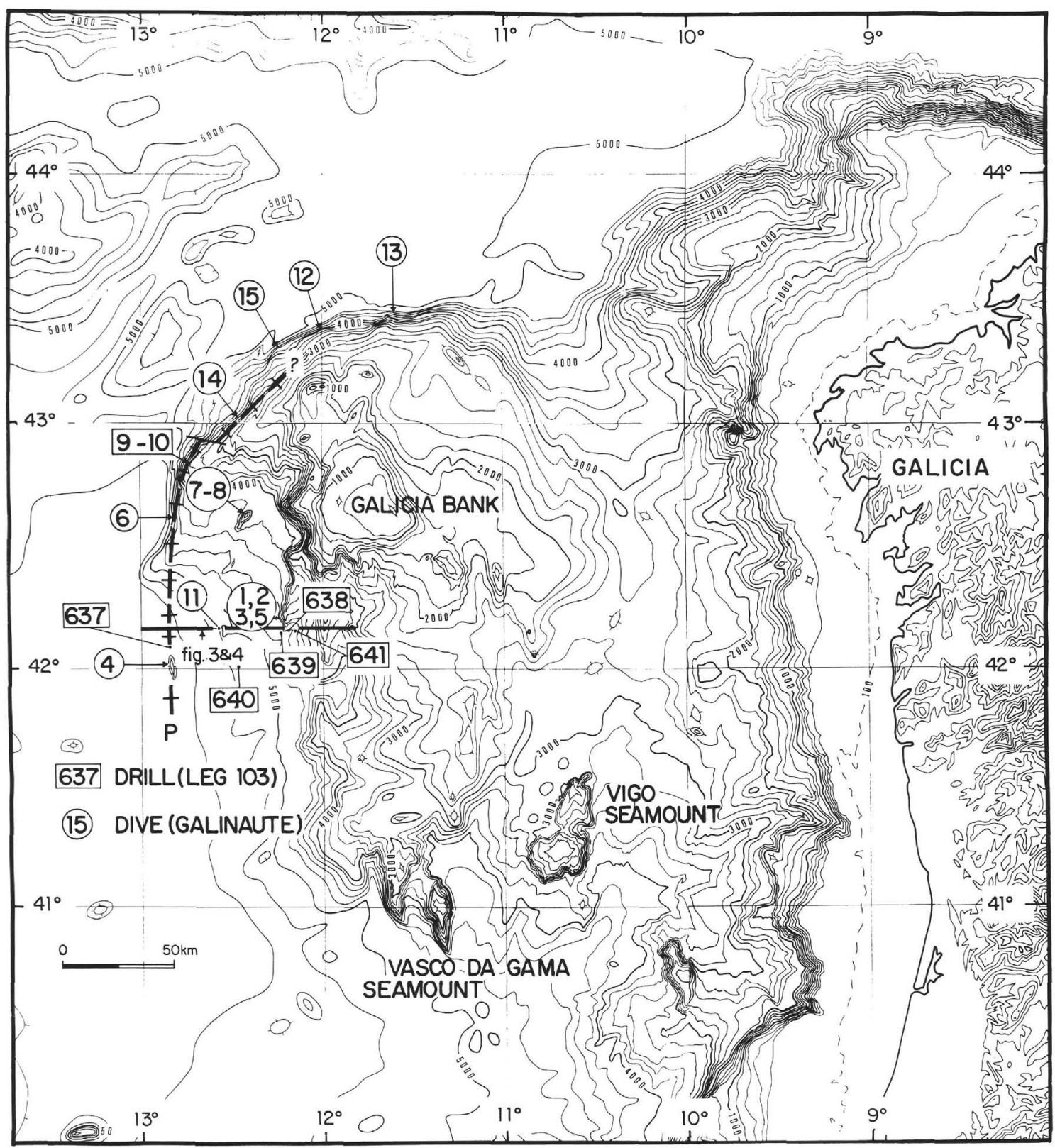

Figure 2. Location of drill sites (boxed numbers; Leg 103) and Galinaute dive sites (circled numbers; see Boillot et al., this volume) on the Galicia margin. Bathymetry in meters, after Lallemand et al. (1985). Location of the seismic line reproduced in Figure 3 and interpreted in Figure 4 is shown. $\mathrm{P}=$ peridotite ridge.

tilting of the main crustal blocks remains problematic (Fig. 5). In other words, a significant amount of thinning of the crust, evidenced by the deepening depositional environment, seems to have preceded - by at least 4 or $5 \mathrm{~m}$.y. - the most prominent indication of crustal extension, the tilting of the blocks.

\section{Thinning of the Continental Crust: Estimation of $\beta$}

For the time being, there are no seismic-refraction data on the drilled area of the margin, and we cannot accurately locate the Moho beneath the thinned continental crust. Nevertheless, continental basement crops out on fault scarps bounding the westward edge of the tilted blocks, including the deepest one. Thus, it is possible to evaluate the crustal thickness by knowing the water depth and assuming isostatic equilibrium of the continental basement (density $=2.8 \mathrm{~g} / \mathrm{cm}^{3}$ ) upon mantle rocks (density $\left.=3.3 \mathrm{~g} / \mathrm{cm}^{3}\right)$. From this, we calculate a crustal thickness of less than $10 \mathrm{~km}$ at Site 638 , including the sedimentary cover $(1.2 \mathrm{~km})$. Assuming an initial thickness of $30 \mathrm{~km}$ for the crust, the thinning coefficient $(\beta)$ was 3.4 during rifting. At dive Site 11 (Fig. 2), which is to the west of and in deeper water than Site 638 , the sampling of continental basement at $5200 \mathrm{~m}$ suggests a local crustal thickness of $6.5 \mathrm{~km}(\beta=4.6)$. Further oceanward thinning of the continental crust is even more dramatic (Fig. 4), as mantle rocks crop out on the peridotite ridge at the western edge of the margin (see the next section).

\section{Estimation of the Amount of Superficial Extension (e)}

We have a sufficient number of good quality seismic profiles to formulate an estimate of the amount of horizontal stretching of the basement from the geometry of normal faults and tilting of blocks between faults. Such an estimate, however, is based on the assumption that tilted blocks are bounded by normal listric 

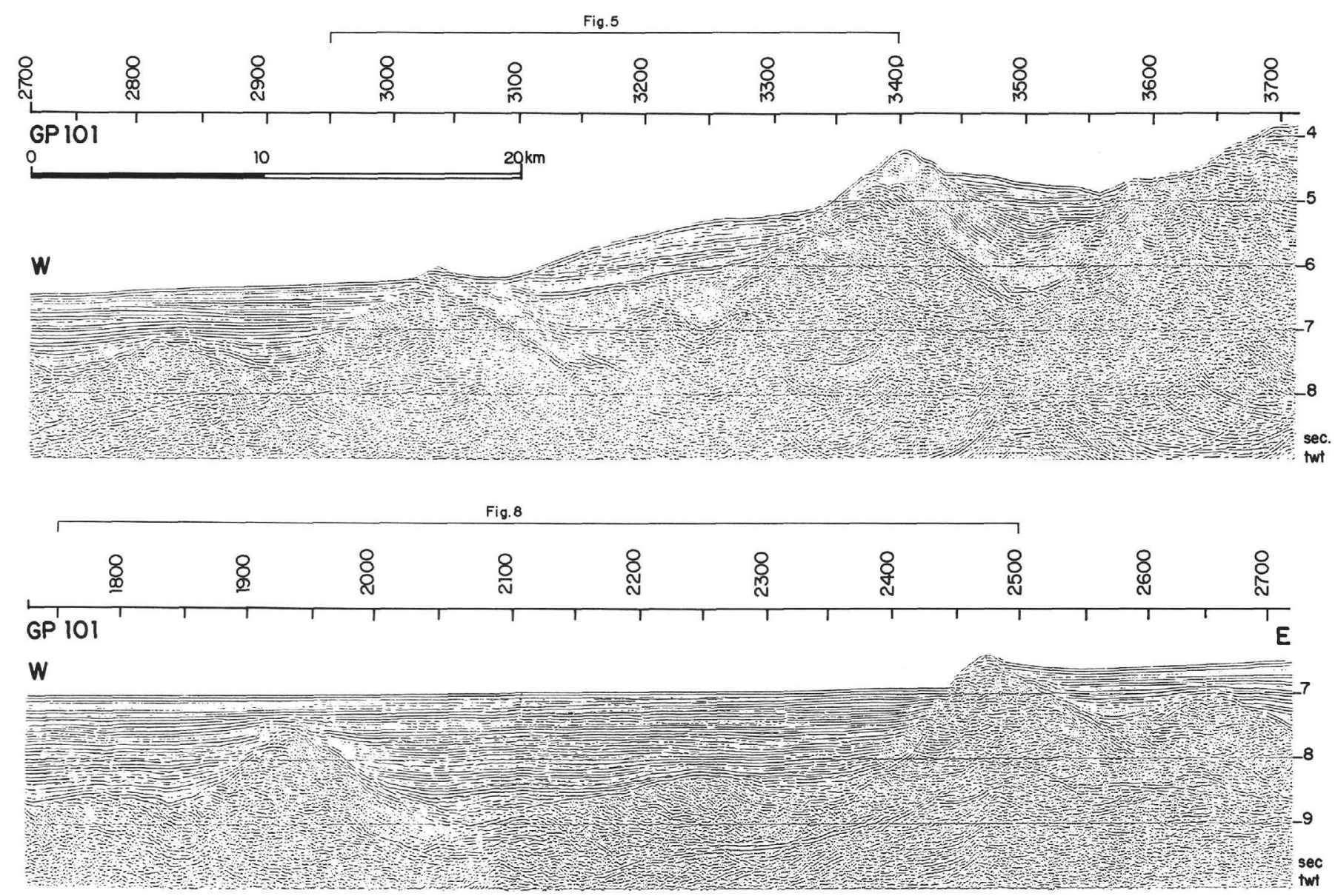

Figure 3. Seismic line GP-101, recorded by the Institut Français du Pétrole (Mauffret and Montadert, 1987), showing the main structural and sedimentary features of the passive Galicia margin (tilted blocks and peridotite ridge). See Figure 2 for location and Figure 4 for interpretation. Detailed sections are given in Figures 5 and 8. Vertical scale in S TWT, horizontal scale is shot points, also on Figure 4.

faults on which the blocks rotated during rifting of the margin (de Charpal et al., 1978; Montadert et al., 1979; Le Pichon and Sibuet, 1981). The geometry of the listric fault is given by the seismic reflector defining the sole of each half-graben, dipping $20^{\circ}-30^{\circ}$ close to the surface and decreasing to $10^{\circ}-15^{\circ}$ at depth (Figs. 3 and 4A). Note that, according to this interpretation, the oceanward slope of a tilted block, when not entirely buried, must be a fault scarp in continuation with the listric fault indicated by the seismic record.

This estimation can be applied to the deep western Galicia margin to calculate the coefficient $e$ (total horizontal stretching of the upper crust). According to Chenet et al. (1982) and Boillot et al. (1986b), $e$ is 1.6 or 1.9, respectively. From the present water depths at drill Site 638 and dive Site 11 (see the preceding section), the thinning factor would be more than 3 and even more than 4 at these respective sites, which is greater than the extension factor. Indeed, crustal stretching, as evidenced by superficial normal faulting, cannot entirely explain the crustal thinning of the margin.

\section{Discussion}

\section{Galicia Margin}

Morphologic observations from the Galinaute cruise make the listric fault interpretation of the seismic records questionable. With the submersible Nautile, we visited several westward escarpments of tilted blocks, especially the deep one (dive Sites 7 , 8, and 11; see Boillot et al., this volume). Where the base- ment crops out, the morphology is comparable from one block to another. Rocky cliffs of several meters to several tens of meters high are separated by flat and smooth areas some hundred meters wide and covered by soft sediment. The slope of the cliffs is about $60^{\circ}$ and looks like a normal fault scarp (Fig. 6). Conversely, the slope of the intervening flat areas does not exceed $10^{\circ}-15^{\circ}$. These observations suggest that the slope of the tilted blocks results from several steeply dipping normal faults arranged in tiers (Fig. 4B) instead of from a gently dipping single fracture $\left(20^{\circ}-30^{\circ}\right)$, as proposed by the listric fault interpretation. Despite its precision, Sea Beam mapping cannot record steps separated by flat areas that are hundreds of meters wide because it smooths the seafloor, showing only the average slope. According to in-situ observations, the slope is actually the envelope of elementary fault scarps, which have a dip considerably greater than that of the overall slope itself. Note that a similar interpretation was considered for Site 639 (Shipboard Scientific Party, 1987d) and was recently proposed by Jansa et al. (this volume) to explain the facies repetition in the Tithonian section recovered at Holes 639A through 639E.

On the seismic lines, the block escarpments visited with the Nautile are prolonged by a well-defined reflector that is usually interpreted as the normal listric fault bounding the crustal block. We are now led to consider this reflector as a paleoslope formed by several stair-stepped elementary normal faults and now buried by post- and syn-rift sediments (Fig. 4B). Like Sea Beam sounding, the seismic survey probably cannot record close fault scarps, and the sole reflector, previously identified as the listric 

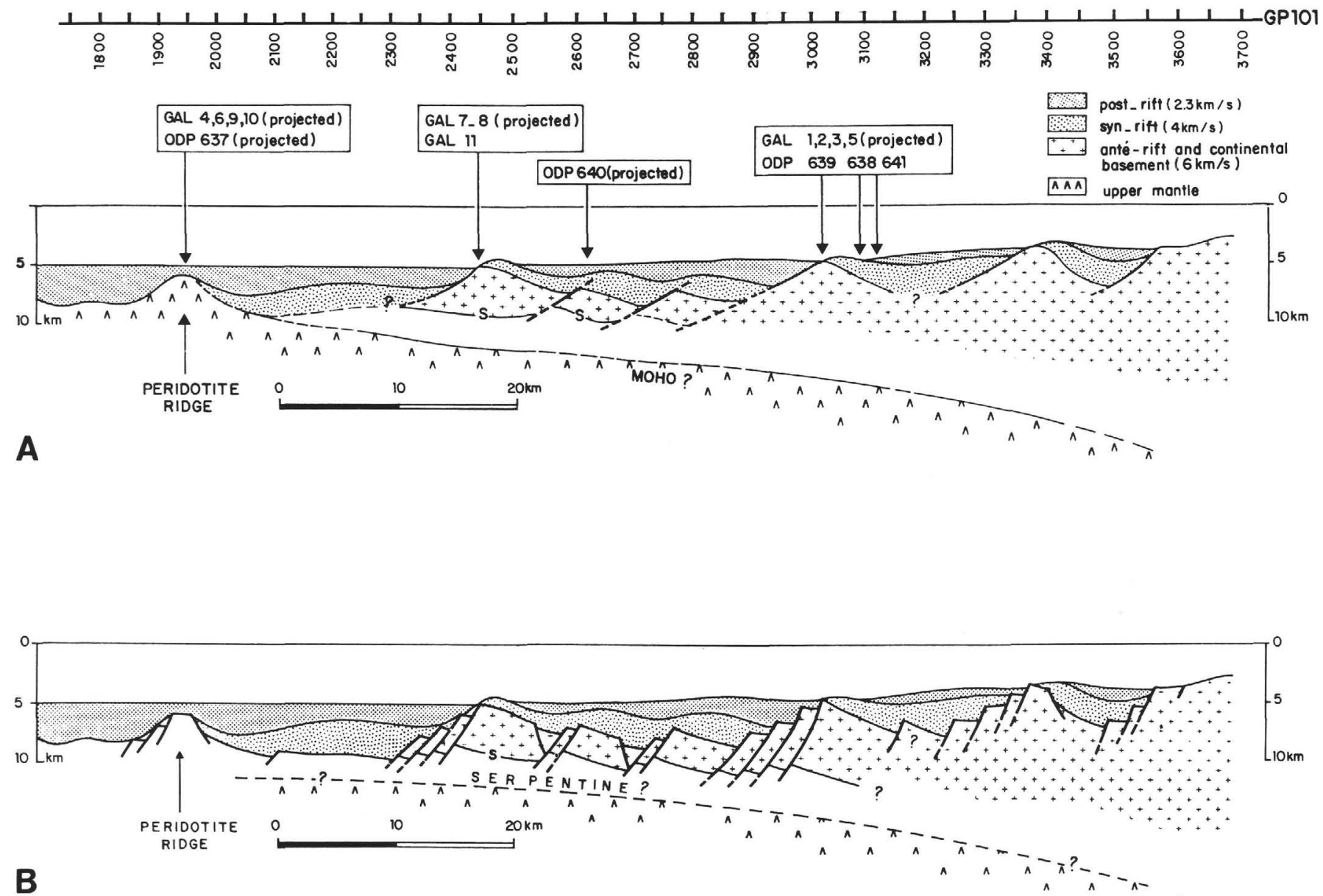

Figure 4. Synthetic cross section of the Galicia passive margin (see Fig. 2 for location), interpreted from seismic line GP-101 (Fig. 3). A. Listric fault interpretation for the normal faults and tilted block (after Boillot et al., 1986a, this volume; see also the same seismic line interpreted by Winterer et al., this volume). B. The steeply dipping normal fault hypothesis, discussed in the text. The location of the Moho assumes isostatic equilibrium, with densities of 2.8 and $3.3 \mathrm{~g} / \mathrm{cm}^{3}$ for the thinned continental crust and upper mantle, respectively (see Fig. 11 for kinematic interpretation of the present structure). $\mathrm{S}=\mathrm{S}$ seismic reflector. Shot points along the top of the figure are also shown in Figure 3.

fault, more likely is the locus of the tops of elementary normal faults, each of which acts as a bright point for the acoustic waves.

If true, this interpretation implies a coefficient of distension, $e$, that is even smaller than that determined by the listric fault hypothesis, as the sum of horizontal throws of steeply dipping elementary faults is less than the horizontal throw of a single gently dipping listric fault. Thus, the discrepancy between the thinning coefficient, $\beta$, and the superficial stretching coefficient, $e$, is increased.

\section{Armorican Margin}

Tilted blocks and listric faults were first described on the Armorican margin (de Charpal et al., 1978; Montadert et al., 1979; Montadert, 1984), and consideration of the seismic lines on which these structures were initially observed must be taken into account by our interpretation. The Armorican and Galicia margins are very similar, in terms of the timing of events as well as the present-day structure, and they have probably experienced similar tectonic processes and evolution.

According to Montadert et al. (1979), dipping reflectors interpreted as listric faults separate a well-layered pre-rift sedimentary sequence from the margin basement (Fig. 7A). If this is true, then each dipping reflector in effect corresponds to a fault instead of a buried paleoslope because it is younger (syn-rift) than the faulted terrain (pre-rift). But is the layered sequence really pre-rift?

The pre-rift Tithonian carbonate of the Armorican margin was drilled at DSDP Site 401, on the top of a tilted block (Montadert, Roberts, et al., 1979). At that site, the drilled carbonate belongs to the acoustic basement and not to the layered sequence. Thus, the age of this layered sequence is uncertain. On the other hand, a similar layer that tilted with the basement, the Valanginian coarse detrital formation, was drilled on the Galicia margin at Site 638. Before Leg 103, this sequence was considered to be pre-rift (see the preceding discussion), and it was surprising to recover Valanginian sandstone instead of the expected Tithonian carbonate, which occurs deeper within the acoustic basement. According to the Leg 103 scientific party, it is highly likely that the layered formation of the Armorican margin that tilted with the basement also belongs to the Early Cretaceous syn-rift sequence and is not a part of the pre-rift carbonate formation (see "Site 638" chapter; Shipboard Scientific Party, 1987c).

Thus, in our opinion, the Armorican margin data do not contradict the proposed interpretation for the dipping reflectors that sole the half-grabens of the Galicia margin. On both margins, dipping reflectors that had been considered as listric faults could be paleoslopes resulting from several highly dipping normal faults distributed along the entire slope of each tilted block 

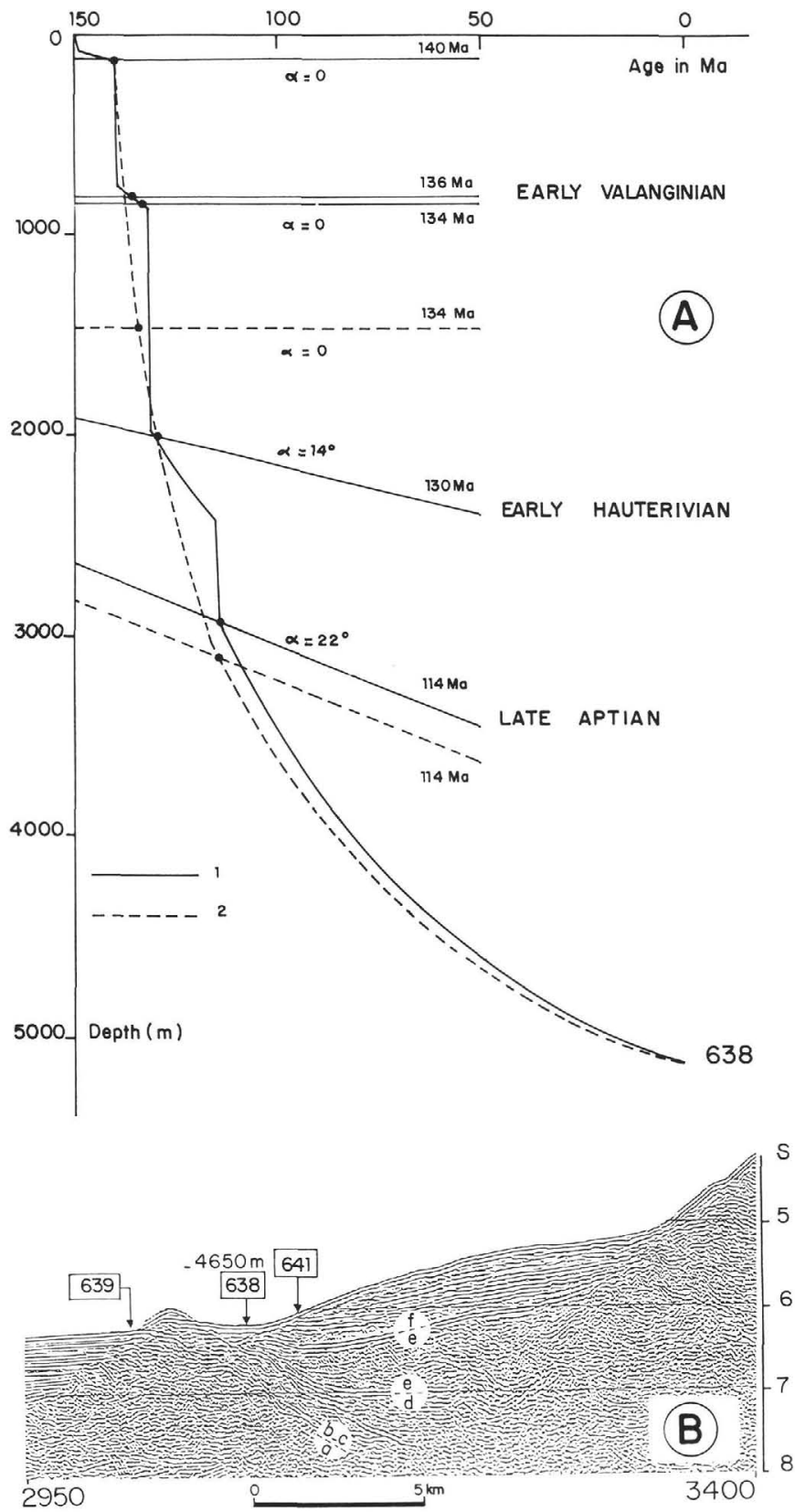

Figure 5. A. Tilting of the crustal block vs. time and subsidence at Site 638. The curves represent the theoretical tectonic subsidence under seawater (i.e., without sediment), calculated using the McKenzie (1978) uniform-stretching model (after Moullade et al., this volume). Line 1 (solid): polyphase distension at 140 and $114 \mathrm{Ma}$. Line 2 (dashed): distension event in the Tithonian (150 Ma) and continuous distension between the Berriasian (140 Ma) and late Aptian (114 Ma). The tilting of the block is evaluated after the interpretation of the segment of seismic line GP-101 shown in Figure 1B, assuming a seismic velocity of $2.3 \mathrm{~km} / \mathrm{s}$ in the post-rift sediment and $4 \mathrm{~km} / \mathrm{s}$ in the syn-rift sediment. B. Section of seismic line GP-101 showing the tilted block where Hole 638 was drilled. $\mathrm{a}=$ Tithonian; $\mathrm{b}$ and $\mathrm{c}=$ Valanginian; $\mathrm{d}=$ Hauterivian; $\mathrm{e}=$ Barremian-upper Aptian; $f=$ uppermost Aptian-present. Vertical scale in s TWT. See Figure 3 for location.

and now buried by syn-rift sediment (Figs. 4B and 7B). Consequently, the dipping reflectors possibly are not the surfaces on which the blocks rotated during rifting. The rotation (about $15^{\circ}-20^{\circ}$ ) could result from slow changes in the dip of the normal faults, decreasing somewhat with depth from $60^{\circ}-70^{\circ}$ for the upper faults to $40^{\circ}-50^{\circ}$ on the axis of each half-graben.

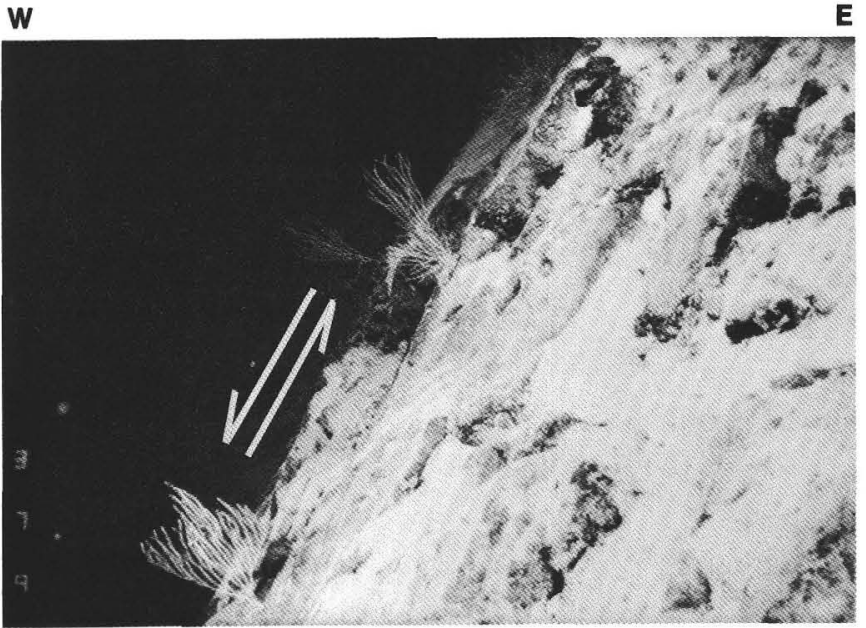

Figure 6. Submarine photograph of an escarpment directly overhanging the abyssal plain at dive Site 11 (see Fig. 2 for location). The escarpment is made of granodiorite and interpreted as a normal fault throw with $70^{\circ}$ dip. Scale: Gorgonia are about $1 \mathrm{~m}$ high.

Whatever the correct interpretation is (single listric fault or several normal faults), it is clear that the amount of superficial stretching that the continental crust underwent is significantly less than the amount of crustal thinning.

\section{THE PERIDOTITE RIDGE}

The Galicia margin is bounded to the west by a north-south basement ridge $10 \mathrm{~km}$ wide, $3 \mathrm{~km}$ high, and at least $130 \mathrm{~km}$ long (Figs. 2-4). In places, the ridge is symmetrical, with each slope dipping about $15^{\circ}$ from the summit; in other places, it resembles a tilted block of the adjacent margin, with the west-facing slope locally more inclined than the east-facing one (Mauffret and Montadert, 1987). The ridge is generally buried except for on a small seamount (Hill 5100) and on the northwest slope of Galicia Bank, as a result of Eocene tectonics there. Dredge haul recovery from Hill 5100 in 1978, drilling at Site 637 in 1985, and five dives of the Nautile in 1986 have produced evidence that the ridge consists of serpentinized peridotite (Boillot et al., 1980, 1986a, this volume; Shipboard Scientific Party, 1987b). The peridotite recovered on the ridge is quite different from the Hercynian peridotite included in the Galicia folded belt of that age (Girardeau et al., this volume). The ridge rock was derived directly from the mantle and was probably emplaced during the Mesozoic in relation with the horizontal stretching of the lithosphere.

\section{Age of the Peridotite Ridge}

At Site 637, the first sediment deposited on the ultramafic basement was found to be latest Cretaceous in age (Doyle, this volume). However, the hole is located close to the top of the ridge, whereas seismic data show deeper and older sediments covering the sides of the ridge (Fig. 8). Seismic lines on the eastern (marginward) side of the ridge show that it is onlapped by a complete post-rift sequence (upper Aptian to the present) and by a thin syn-rift sequence (deposited pre-late Aptian). On the oceanic side, we failed to recognize pre-rift sediments. Thus, emplacement of the ridge seems to have occurred at the very end of the rifting, just before seafloor spreading started in this part of the Atlantic during the late Barremian or early Aptian (120 Ma).

The ridge is approximately in line with the M0 magnetic anomaly (actually some kilometers to the west; see Figs. 1 and 2). The M0 anomaly is identified just to the south (Groupe Galice, 1979; Guennoc et al., 1979; Olivet et al., 1984; Verhoef et al., 

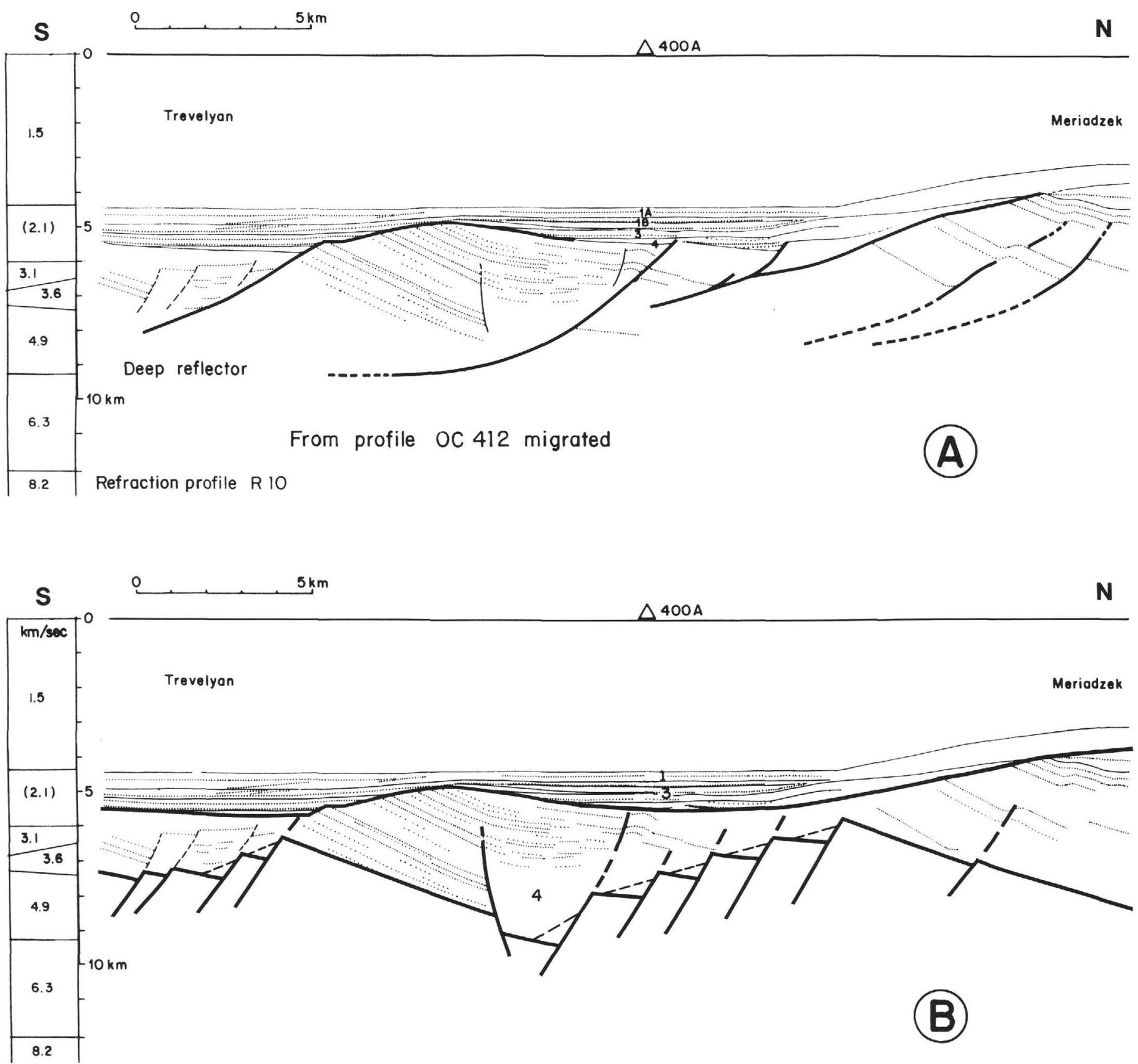

Figure 7. Two possible interpretations for Institut Français de Pétrole seismic line OC-412, recorded on the Armorican margin. A. The listric fault interpretation by Montadert et al. (1979). Seismic velocities from refraction data along the left of the figure. B. The high-dipping normal fault interpretation (this paper). 1-3 = post-rift sediments; $4=$ syn-rift sediments, considered as pre-rift in the previous interpretation.

1986; Srivastava and Tapscott, 1987) and tentatively recognized on the ridge itself (Sibuet and Ryan, 1979). We conclude that the ridge and the M0 anomaly are of approximately the same age, about $120 \mathrm{Ma}$, according to the Kent and Gradstein (1985) time scale. Thus, as far as the timing of the emplacement of the ridge at the seafloor is concerned, there is good agreement between seismic and magnetic data.

\section{Location of the Ridge at the Ocean/Continent Boundary}

The basement was not sampled to the west of the ridge, but refraction data suggest typical oceanic crust (Grau et al., 1973). Also, the contact between basement and sediment seen on seismic lines recorded to the west of the peridotite ridge looks like the typical diffracting top of basaltic layers in other oceans. Therefore, we presume that the basement on the ocean side of the peridotite ridge consists of oceanic crust belonging to the Cretaceous magnetic quiet zone. However, ultramafic seafloor could extend farther west beyond the ridge where peridotite was drilled.

Eastward, transition with the typical continental crust sampled at dive Site 11 (Fig. 2) occurs beneath a 20-km-wide sedimentary basin (Figs. 4 and 8 ). Indeed, the peridotite ridge constitutes the boundary between continental crust to the east and probable Atlantic oceanic crust to the west. It forms a continuous belt where the crust is missing and where the mantle rocks crop out directly on the seafloor. The peridotite ridge probably represents the axis of the Early Cretaceous continental rift of 

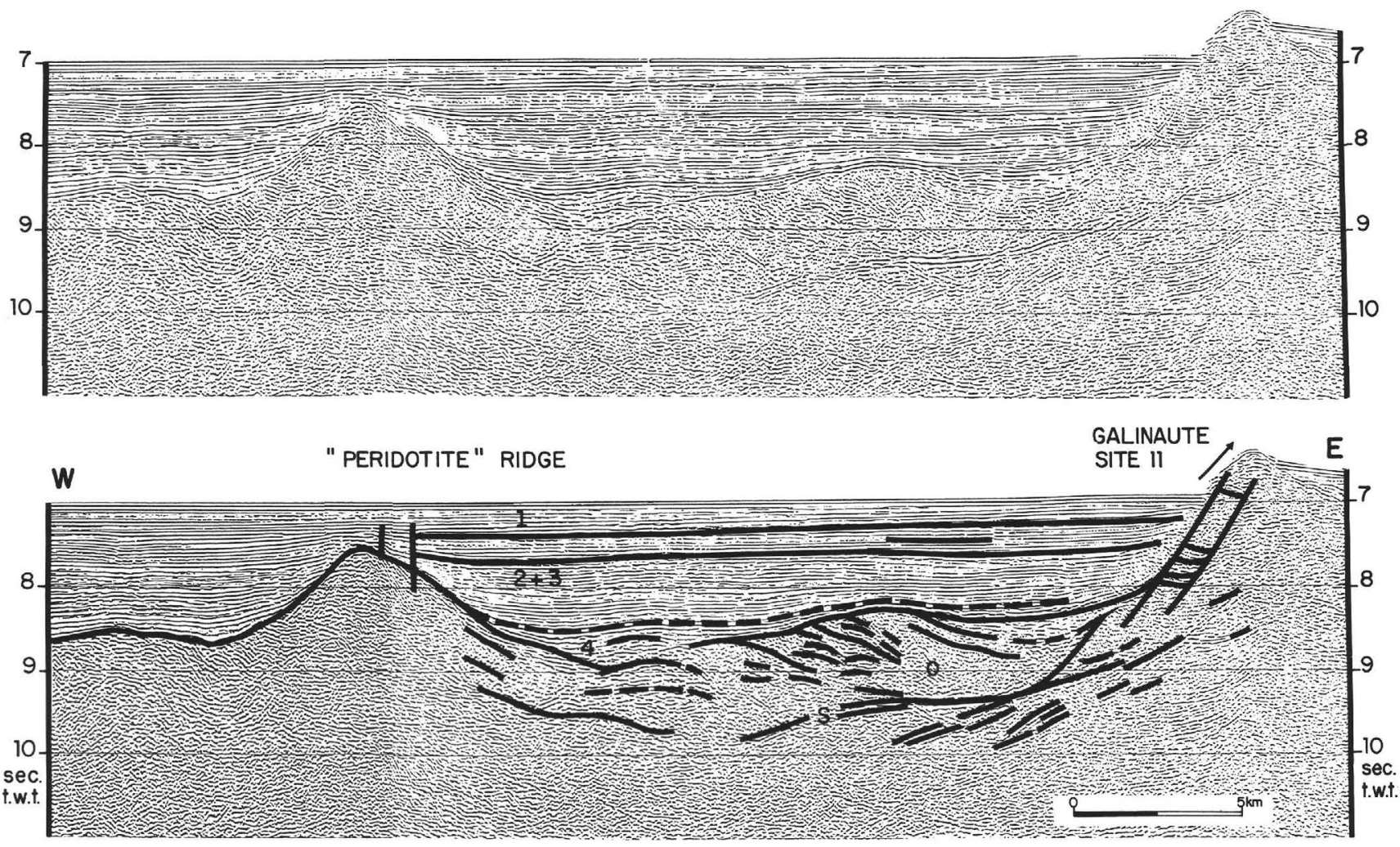

Figure 8. Section of Institut Français du Pétrole seismic line GP-101 (see Fig. 3 for location) across the sedimentary basin, bounded by the peridotite ridge to the west and by the deepest continental block of the margin to the east. Interpretation by Mauffret and Montadert (1987) is shown in the lower part: $1-3$ = post-rift sediment; 4 = syn-rift sediment; $O=$ olistostrome, included in the syn-rift sediment on the Figure 4 cross section. The $S$ reflector seems to extend the eastern flank of the peridotite ridge.

Galicia, which reached the last stage of its evolution $120 \mathrm{Ma}$ ago.

\section{Petrology and Structure of the Peridotite Drilled at Site 637 (Table 1 and Fig. 9)}

The peridotite recovered by drilling on the Galicia margin is deeply serpentinized (up to $80 \%$ ) and often replaced by calcite. However, it contains relicts of primary phases (i.e., olivine, orthopyroxene, clinopyroxene, spinel, and plagioclase). As pointed out by the behavior of $\mathrm{Ti}$ in the mineral assemblage, the plagioclase seems to have grown mainly around spinel, possibly in subsolidus conditions (Kornprobst and Tabit, this volume). However, some interstitial crystals and irregular thin veinlets could have resulted from "in-situ" crystallization of trapped liquid (Girardeau et al., this volume). According to modal repartition of the primary phases, most of the studied samples belong to diopside-spinel or spinel plus plagioclase-bearing harzburgites and lherzolites. "Diopside-less" harzburgites and dunites are scarce. The rock also displays a thin clinopyroxenite banding locally (Girardeau et al., this volume; Kornprobst and Tabit, this volume).

The peridotite underwent some partial melting, resulting in 5\%-10\% melt extraction (Evans and Girardeau, this volume). Partial melting started at a relatively high temperature $\left(1200^{\circ}\right.$ $1250^{\circ} \mathrm{C}$ ) and pressure (>10 kbar) in the spinel field. The last extracted liquid perhaps left the rock at a lower temperature $\left(1100^{\circ}-970^{\circ} \mathrm{C}\right)$ and pressure ( $\simeq 8 \mathrm{kbar}$ or less) in the plagioclase facies field, indicating that melting occurred in hydrous conditions (Girardeau et al., this volume), as in Zabargad peridotites (Bonatti et al., 1986; Nicolas et al., 1987).

Initially, the rock was coarse grained and locally orthopyroxene rich, as deduced from microstructural data. Later, it under- went plastic deformation in a noncoaxial regime, probably by simple shear. The deformation began at high temperature (above $1000^{\circ} \mathrm{C}$ ) and under low-stress conditions $(\simeq 100 \mathrm{bar})$. It ended at lower temperature $\left(\simeq 850^{\circ} \mathrm{C}\right)$ and under very high strain $(\gamma=$ 12) and stress (1.8-kbar) conditions, inducing development of the penetrative $S_{1}$ mylonitic disrupted foliation recognizable in all samples (Girardeau et al., this volume). On average, the foliation dips $30^{\circ}$ in the upper $50 \mathrm{~m}$ of the drilled section and up to $70^{\circ}$ in the lower $25 \mathrm{~m}$ (see Shipboard Scientific Party, 1987b). The lineation is downdip into the foliation, except in some samples where it stands at $45^{\circ}$ from the downdip line. According to shipboard paleomagnetic measurement and direct observation of the peridotite from diving at Site 4 , the foliation is dipping to the east or northeast, and the mean lineation trends mostly in these directions. Shear-sense measurement indicates a top-to-theeast sense of shear, which means that the plane along which the shearing occurred had a mostly normal component of movement.

High-temperature $\left(800^{\circ}-900^{\circ} \mathrm{C}\right)$ amphibole developed in static conditions after the mylonitization event (Agrinier et al., this volume). Then the peridotite experienced intensive hydrothermal alteration at decreasing temperatures $\left(750^{\circ}-350^{\circ}\right.$ to $\left.100^{\circ} \mathrm{C}\right)$, resulting in the formation, under static conditions, of various types of amphiboles after clinopyroxene and of serpentine minerals after olivine or orthopyroxene. This was followed by brittle normal faulting that resulted in eastward-dipping normal faults superimposed on the foliation, after which calcite precipitated into the fractures at low temperatures $\left(<100^{\circ} \mathrm{C}\right)$. Finally, the seafloor peridotite underwent weathering at very low temperatures, inducing the transformation of most phases into clay minerals or Fe-oxides (Boillot et al., 1980; Agrinier et al., this volume; Evans and Baltuck, this volume; Kimball and Evans, this volume). 
Table 1. Succession of structural and metamorphic events experienced by the Galicia margin peridotite, from studies in this volume by Evans and Girardeau, Girardeau et al., Kornprobst and Tabit, Agrinier et al., Kimball and Evans, and Evans and Baltuck.

\begin{tabular}{|c|c|c|c|}
\hline Succession of events & $\begin{array}{c}\text { Assumed } \\
\text { temperature } \\
\left({ }^{\circ} \mathrm{C}\right)\end{array}$ & $\begin{array}{l}\text { Assumed } \\
\text { depth } \\
(\mathrm{km})\end{array}$ & $\begin{array}{c}\text { Structural } \\
\text { event } \\
\text { (W-E) }\end{array}$ \\
\hline \multicolumn{4}{|l|}{ Event 5} \\
\hline $\begin{array}{l}\text { Fracturing, then infilling of } \\
\text { fractures by calcite } \\
\text { (and serpentine) }\end{array}$ & $\leq 10$ & 0 & \\
\hline \multicolumn{4}{|l|}{ Event 4} \\
\hline Ubiquitous serpentinization & $\begin{array}{l}110-55 \\
(<300)\end{array}$ & $<5$ & \\
\hline \multicolumn{4}{|l|}{ Event 3} \\
\hline $\begin{array}{l}\text { Beginning of serpentinization(?) } \\
\text { Crystallization of amphiboles in } \\
\text { static conditions: } \\
\text { hornblende and tremolite } \\
\text { pargasite }\end{array}$ & $\begin{array}{c}750 \\
900-800\end{array}$ & & $\mathrm{~S}_{1}$ \\
\hline \multicolumn{4}{|l|}{ Event 2} \\
\hline $\begin{array}{l}\text { Stretching and mylonitization at } \\
\text { decreasing temperature } \\
\text { New foliation } S_{1}\end{array}$ & $\begin{array}{r}850 \\
1000\end{array}$ & 7 & \\
\hline \multicolumn{4}{|l|}{ Event 1} \\
\hline $\begin{array}{l}\text { End of the partial melting in } \\
\text { hydrous conditions in the } \\
\text { plagioclase facies } \\
\text { Beginning of stretching } \\
\text { Beginning of partial melting }\end{array}$ & $\begin{array}{l}1100 \\
1250\end{array}$ & $\leq 30$ & \\
\hline \multicolumn{4}{|l|}{ Event 0} \\
\hline $\begin{array}{l}\text { Initial peridotite: coarse-grained } \\
\text { spinel lherzolite; initial foliation } \mathrm{S}_{0}\end{array}$ & $?$ & ? & $\mathrm{S}_{0}$ \\
\hline
\end{tabular}

Thus, the drilled peridotite differs significantly from typical oceanic harzburgite. Conversely, its phase composition is roughly similar to most oceanic diopside-bearing harzburgites and lherzolites, although the rock is less depleted in basaltic components and more enriched in magmaphile elements such as $\mathrm{Na}$, $\mathrm{Al}$, and $\mathrm{Ti}$. It also contains some plagioclase, developed around spinel or as interstitial crystals, which is generally missing in typical oceanic rocks. On the other hand, the mineral composition is similar to that of the Zabargad Island peridotite (Bonatti et al., 1981, 1986; Nicolas et al., 1985, 1987). It also resembles some obducted suboceanic or subcontinental mantle peridotites exposed at Lanzo or Ronda, for example, whereas the Galicia margin peridotite differs significantly from the western Pyrenean lherzolite and from all Variscan peridotites, including the Lizard massif (Kornprobst and Tabit, this volume; Girardeau et al., this volume). It is also quite different from typical ophiolitic harzburgite (Evans and Girardeau; this volume; Kornprobst and Tabit, this volume).

\section{INTERPRETATION OF THE PERIDOTITE RIDGE}

The peridotite drilled by the JOIDES Resolution and recently sampled with the Nautile on the Galicia margin is probably not part of a Hercynian sheet made of ophiolite and tilted with crustal blocks. All the structural and petrological data support a direct upper mantle origin. The uplift of the mantle rocks from a depth of several tens of kilometers to the surface is evidenced by their mineralogical evolution and their deformation, both of which imply a progressive drop of temperature and pressure.

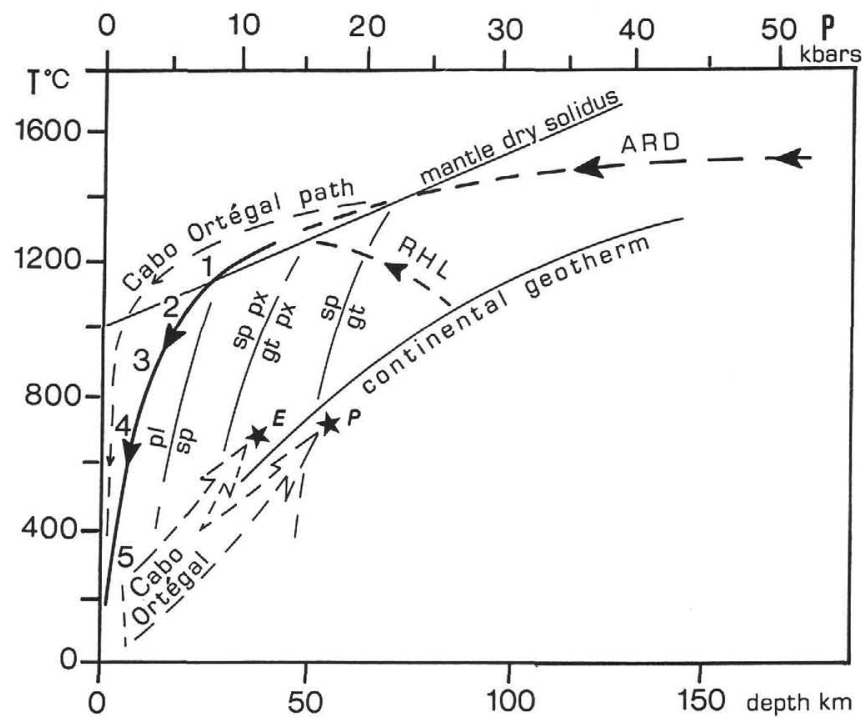

Figure 9. Pressure-temperature evolution of the peridotite drilled at Site 637 compared to that of Cabo Ortégal ophiolite (Girardeau et al., this volume). $\mathrm{gt}=$ garnet; $\mathrm{sp}=$ spinel; $\mathrm{px}=$ pyroxene; $\mathrm{pl}=$ plagioclase; 1 = end of melting; 2 = ductile shearing of the peridotite; $3=$ end of ductile shearing; $4=$ beginning of hydrothermal alteration; $5=$ ubiquitous serpentinization; ARD = adiabatic rising diapir; RHL = reheated lithosphere; $\mathrm{E}$ and $\mathrm{P}=$ eclogite and peridotite, respectively, at Cabo Ortégal.

The peridotite of the Galicia margin resembles neither a typical oceanic mantle nor a typical continental one. More likely, it represents the mantle underlying an active continental rift or an incipient oceanic rift. This interpretation is in good agreement with the location of the peridotite ridge at the ocean/continent boundary.

According to estimates of the prevailing physical conditions during the melting and deformation of the peridotite, we should consider its behavior during the first stage of its emplacement to be the same as that of the asthenosphere. Specific petrological features of the rock suggest that it was derived either from relatively deep subcontinental lithosphere, reheated sufficiently to melt, or from a piece of asthenosphere mantle that was slightly remelted during an adiabatic uplift.

Structural study scraps the transform fault hypothesis for the emplacement of the peridotite (Girardeau et al., this volume). The orientation of the stretching lineation to the east establishes that the rock was deformed by divergent lithospheric motion and not by strike-slip motion. Thus, we conclude that the rifting between the Iberian and American plates during the Mesozoic resulted in the emplacement of upper mantle rocks at the rift axis. This new concept is one of the most significant results of the Leg 103 and Galinaute cruises.

The peridotite ridge was emplaced at the foot of the present margin probably during the late Barremian or early Aptian $(120 \mathrm{Ma})$. We suppose that the final emplacement was associated with the last stage of brittle fracturing of the serpentine. The shape of the ridge, locally resembling a tilted block, could result from this late normal faulting event, involving cold serpentinized ultramafic basement. This possible late tilting of the peridotite must be taken into account in discussing the present eastward dip of the $S_{1}$ foliation.

We currently have no data constraining the timing of the first stages of the peridotite evolution before its serpentinization. However, we think that the progressive uplift of the peridotite can be correlated to different stages in the Mesozoic rifting of the margin. 


\section{S SEISMIC REFLECTOR}

The S reflector is either a single strong seismic reflector, or a sequence of several elementary reflectors. It occurs in the deep margin basement at depths ranging from 1.6 to $0.6 \mathrm{~s}$ two-way traveltime (TWT) from the bottom of the layered sedimentary cover (Mauffret and Montadert, 1987). In the basin separating the peridotite ridge from the deeper tilted block of the margin, it seems to emerge at the surface of the basement and was not identifiable to the west, beneath the peridotite ridge itself (Fig. 8). Conversely, the $\mathrm{S}$ reflector deepens gradually to the east and disappears from the seismic record at Site 638 (Figs. 3 and 4).

This enigmatic feature was discovered by de Charpal et al. (1978) and has been interpreted as the ductile/brittle boundary within continental crust, a level where listric faults rooted during the rifting of the margin (Montadert et al., 1979; Mauffret and Montadert, 1987). More recently, the Leg 103 Scientific Party interpreted the $\mathrm{S}$ reflector to be the contact between the basement of the margin (including possible Tithonian carbonates) and the syn-rift sediments that more or less detached and slid during rifting (see "Site 640" chapter; Shipboard Scientific Party, 1987e). This interpretation is now obsolete because continental basement was sampled with the Nautile on the deeper tilted block of the margin, a place where the $\mathrm{S}$ reflector is obvious on seismic lines (dives 7, 8, and 11; see Boillot et al., this volume) (Figs. 4 and 8).

The S reflector also exists on the deep Armorican margin. Recently, Barbier et al. (1986) and Le Pichon and Barbier (1987) concluded that it constitutes a tectonic discontinuity between a deep, high-velocity basement $\left(\mathrm{V}_{p}=6.5\right.$ to $\left.7.5 \mathrm{~km} / \mathrm{s}\right)$ and a shallower, lower velocity layer $\left(\mathrm{V}_{p}=6\right.$ to $\left.4.6 \mathrm{~km} / \mathrm{s}\right)$ that includes both continental basement and indurated sediment. The $\mathrm{S}$ reflector is interpreted as a detachment fault that transformed the superficial distension of the Bay of Biscay rift into the lower crust, where ductile stretching is assumed to occur at the same time.

The lack of seismic-refraction data on the Galicia margin makes comparison with the Armorican margin difficult. However, the $\mathrm{S}$ reflector is very similar in the two margins, and it would be very surprising if it does not result from the same processes at both places. We can summarize the preceding review as follows, extending the results of studies on the Armorican margin to the Galicia margin:

1. The $S$ reflector extends into or beneath the very thinned continental crust of the margin. It reaches the surface of the basement at or close to the ocean/continent transition and, conversely, dips gradually on the continental side, disappearing from the seismic record at 2 or $3 \mathrm{~s}$ TWT below the seafloor.

2 . The $\mathrm{S}$ reflector is probably a tectonic contact between rocks with contrasting physical properties. It can be interpreted as the trace of a detachment fault.

3. The $\mathrm{S}$ reflector is generally flat. Local differences in level can result from tectonic ramp features and/or late normal faulting.

The new data obtained through drilling and diving do not directly concern the S reflector; nevertheless, the sampling of serpentine on the basement ridge bounding the margin and the $S$ reflector could tell us something about its nature and significance. Although the seismic records are unclear for the sedimentary basin bounding the peridotite ridge to the east, it seems that the $\mathrm{S}$ reflector prolongs the slope of the ridge beneath the tilted blocks of the margin (Fig. 8). If this is true, the $\mathrm{S}$ reflector should be the contact between the continental basement (the tilted blocks) and the serpentinized peridotite. Such a structure would explain the high acoustic impedance contrast giving rise to the reflector on the seismic records, as well as the tectonic na- ture of the $\mathrm{S}$ reflector, because the serpentine is a good candidate for décollement. The presence of serpentine beneath the tilted blocks could also explain the tilting and faulting of these blocks because both processes need a décollement surface and/ or a mobile layer to occur (Brun and Choukroune, 1983; Brun et al., 1985).

At Site 637 , the ultramafic basement was found at $5400 \mathrm{~m}$ below the ocean surface. Assuming densities of $2.9 \mathrm{~g} / \mathrm{cm}^{3}$ for the serpentine and $3.3 \mathrm{~g} / \mathrm{cm}^{3}$ for the fresh peridotite, we can predict a 5-6-km-thick serpentine layer from simple isostatic calculation. On the other hand, the hydrothermal process responsible for serpentinization can occur at a depth of several kilometers in the ocean. Thus, it is reasonable to propose that the serpentine layer extends laterally from the peridotite ridge, and the hydrothermal alteration of mantle rocks occurred to the east beneath a very thinned and faulted continental crust. For these circumstances, we propose to distinguish (1) the seismic Moho, that is, the boundary between serpentine and fresh peridotite (the hydrothermal front), and (2) the $\mathrm{S}$ reflector, presently assumed to be the contact between the continental crust and the mantle-derived serpentine and formerly interpreted as a detachment fault (see the next section for further discussion). Despite the speculative nature of this hypothesis, we think that it explains many of the features on the deep Galicia margin (Fig. 4B).

\section{PROCESSES FOR CRUSTAL THINNING AND EMPLACEMENT OF MANTLE ROCKS ON THE SEAFLOOR: A DISCUSSION}

From study of the Galicia passive continental margin, it appears that the thinning of the continental crust and emplacement of the peridotite on the seafloor are closely associated in space and time. In space, the peridotite ridge at the ocean/continent boundary trends north-south, as do the tilted blocks of the margin, and, at least locally, resembles these tilted blocks in shape, height, and width. In time, the peridotite ridge was probably emplaced at the very end of the rifting, as an ultimate effect of the crustal thinning, just before oceanic crustal accretion started. Furthermore, we think that this discussion must concern both processes controlling the thinning of the continental crust and the upwelling of mantle rocks, including their final emplacement on the seafloor bounding the margin.

From the preceding sections, constraints on models for the processes of crustal thinning and peridotite emplacement at the seafloor are (1) the delay of the block tilting relative to the timing of deepening and subsidence (i.e., crustal thinning) of the margin; (2) the discrepancy between the amount of superficial horizontal distension of the continental basement and the amount of crustal thinning, at least on the deep margin; (3) the presumption that thinning of the crust occurred mainly at the expense of its lower part, as no in-situ granulite rocks were recovered at the edge of the margin; (4) the probable partial melting of the peridotite at a high temperature during the first stage of its uplift; (5) the deformation the peridotite, experienced in a simple-shear regime, which excluded a pure shear stretching of the rock (see discussion on that point in Brun and Choukroune, 1983; Gibbs, 1984; Spencer, 1984; Lister et al., 1986; and Coward, 1986); and (6) the relationship between the thinning of the continental crust and the emplacement of mantle rocks on the seafloor, as emphasized above.

These constraints suggest models combining heterogenous stretching for lithosphere and gliding along detachment faults. Two cases that differ in the location and attitude of the detachment fault can be considered: either the fault is rooted in the crust (see application of this model to the Armorican margin by Le Pichon and Barbier, 1987) or the fault cuts through the whole crust and roots in the upper mantle, as proposed by Wernicke $(1981,1985)$. In the first case, some asthenosphere diapirism 
has to be considered to account for the uplift of peridotite onto the seafloor, a process that is not necessary in the second model because the peridotite can be emplaced by a simple tectonic denudation process (Boillot et al., 1986b, 1987). In the following sections, we shall discuss these two distinct models of detachment faulting and asthenosphere diapirism in light of the data recovered on both the crustal and mantle basement of the Galicia margin.

\section{Tectonic Denudation of the Upper Mantle by Normal Shear of the Lithosphere}

Wernicke (1981, 1985) and Wernicke and Burchfield (1982) conceived a model that explains the thinning of the continental crust and lithosphere by movements along a gently dipping $\left(15^{\circ}\right)$ normal detachment fault that cuts through the entire lithosphere. Boillot et al. (1986b, 1987) further extended the model by suggesting that movements along the detachment fault can result finally in exposure of the upper mantle (Fig. 10). They applied this model to the Galicia margin, assuming that the detachment fault was dipping and plunging to the east, beneath the margin. The hypothesis has important implications that can be tested by our field data:

1. There is not necessarily a relationship between the amount of superficial stretching and the amount of crustal thinning. On the hanging-wall side, the shallow normal faults are antithetic structures to the master detachment fault. On the footwall side, the tilted crustal blocks are allochthonous slices, left behind along the surface of the detachment fault. Thus, the two margins of the ocean will be asymmetric.

The discrepancy between the amount of superficial distension and the amount of crustal thinning is well supported on the Galicia margin (see the preceding section). On this point, the model fits the data. However, for relationships between thinning and stretching, models involving detachment faults or different amounts of extension in the upper and lower parts of the crust (Royden and Keen, 1980) agree with the data. The possible asymmetry between the two conjugate margins, Galicia and Newfoundland, is somewhat difficult to show because of the thick sedimentary layer covering the basement structures on the western Atlantic margin. However, the structures of the deep Newfoundland margin seem to be different from that of the Galicia margin (Parson et al., 1985; de Voogd and Keen, 1987; Keen and de Voogd, 1988).

2. According to the assumed location and eastward dip of the detachment fault (Fig. 10), the thinning of the continental crust principally affects the lower crust of the Galicia margin. This implication of the model is in good agreement with the nature of the upper crust of the continental basement sampled at the western edge of the margin. It is also in agreement with the westward thinning of the lower Hercynian crust beneath the Galicia mainland near the margin (Cordoba et al., 1987). Conversely, the continental basement at the edge of the Newfoundland margin has to be made of lower continental crust, that is, mainly of granulitic rocks. Unfortunately, data to test that implication are not available.

3. A detachment fault rooted in the mantle would explain the exposure of upper mantle rocks at the end of the rifting period (Fig. 10). Thus, the S reflector, which was interpreted in the preceding discussion as the continental basement/serpentine contact, could be the shallower part of the detachment fault, possibly offset by late faulting, and as such, would separate the upper continental crust material from the mantle rocks altered by oceanic hydrothermal processes (Fig. 11). In addition, this interpretation accounts for the observed delay between deepening and block tilting for the margin (see the first part of this section).
4. Along the assumed detachment fault, the mantle rocks initially will experience ductile deformation at great depth, and only in the later stage of faulting, when the rocks are near the surface, will they experience brittle deformation. Theoretically, the kinematic picture does not change appreciably as the shearing progresses, and late-stage brittle deformation is superimposed on the ductile deformation with the same sense of shear.

Such a structural evolution was effectively evidenced in the drilled peridotite of the Galicia margin, with a top-to-the-east sense of shearing. Note that the initial eastward dip of the shear planes (presently $30^{\circ}-70^{\circ}$ ) was possibly increased by late tilting of the peridotite ridge (see Fig. 11 and the preceding discussion on the shape of the ridge). Thus, in our consideration of the geometry of the shear planes and the kinematics of the deformation, the data fit very well with the model proposed in Fig. 10.

However, the physical conditions inferred for melting (temperature $\simeq 1250^{\circ} \mathrm{C}$ and pressure $>10 \mathrm{kbar}$ ) and deformation (temperature decreasing from $\simeq 1000^{\circ}$ to $850^{\circ} \mathrm{C}$ for ductile shearing) of the peridotite require that the peridotite come either from the lower part of the lithosphere or from an ascending bulge of asthenosphere. If we accept that the peridotites were emplaced by tectonic denudation of the lower lithosphere, a low-angle fault must be assumed to cut through the entire lithosphere, and we have to expect a large belt of ultramafic seafloor bounding the Newfoundland margin, representing the section of the lithosphere exposed at the Earth's surface by the detachment faulting. This conclusion is currently unverifiable and somewhat unrealistic, even if some tilted crustal blocks of continental nature were emplaced upon peridotite as slices left behind on the detachment fault surface during rifting.

This difficulty leads us to consider the asthenosphere diapirism model as an alternative or supplementary interpretation, at least concerning the peridotite emplacement.

\section{Asthenospheric Vertical Diapirism (Fig. 12)}

Because Zabargad peridotites experienced some melting and high-temperature-low-stress deformation during their uplift, asthenospheric diapirism has been proposed to explain their emplacement onto the Earth's surface (Nicolas et al., 1987). Such a process of mantle uplift can be related either to the advection motion of the asthenosphere or to the density contrast that exists between the hot ascending melting material and the surrounding colder rocks (true diapirism) (Nicolas, 1984, 1986a, 1986b; Kornprobst and Vielzeuf, 1984; Vielzeuf and Kornprobst, 1984).

Whatever the model for the thinning of the lithosphere and the forces responsible for this process, a significant elevation of the thermal gradient, and therefore, some upwelling of the asthenosphere, appears to be associated with the rifting process. Thermal gradient instability occurs beneath the rift, producing melting of the rising mantle as it crosscuts the peridotite solidus curve. The amount of melting experienced by the peridotite seems to depend on the depth at which the ascending material reenters the subsolidus field as it cools beneath the overlying cold lithosphere. Accordingly, the upper mantle beneath continental rifts or incipient basins seems to be composed mainly of spinel- or plagioclase-lherzolites, respectively, and of harzburgites beneath ridges having spreading rates up to $1 \mathrm{~cm} / \mathrm{yr}$ (Boudier and Nicolas, 1985; Nicolas, 1986a, 1986b).

Beneath incipient basins and spreading ridges, the asthenospheric material ascending by advection motion seems to more or less constitute an open wedge, in accordance to the ascending/spreading rate. This wedge displays the geometry of the flow (Ave Lallemand and Carter, 1970; Nicolas et al., 1971), and the deformation regime and foliation pattern in such a wedge seem to be quite simple. As shown by studies on ophiolites, the main foliation results primarily from simple shear that has a steep at- 

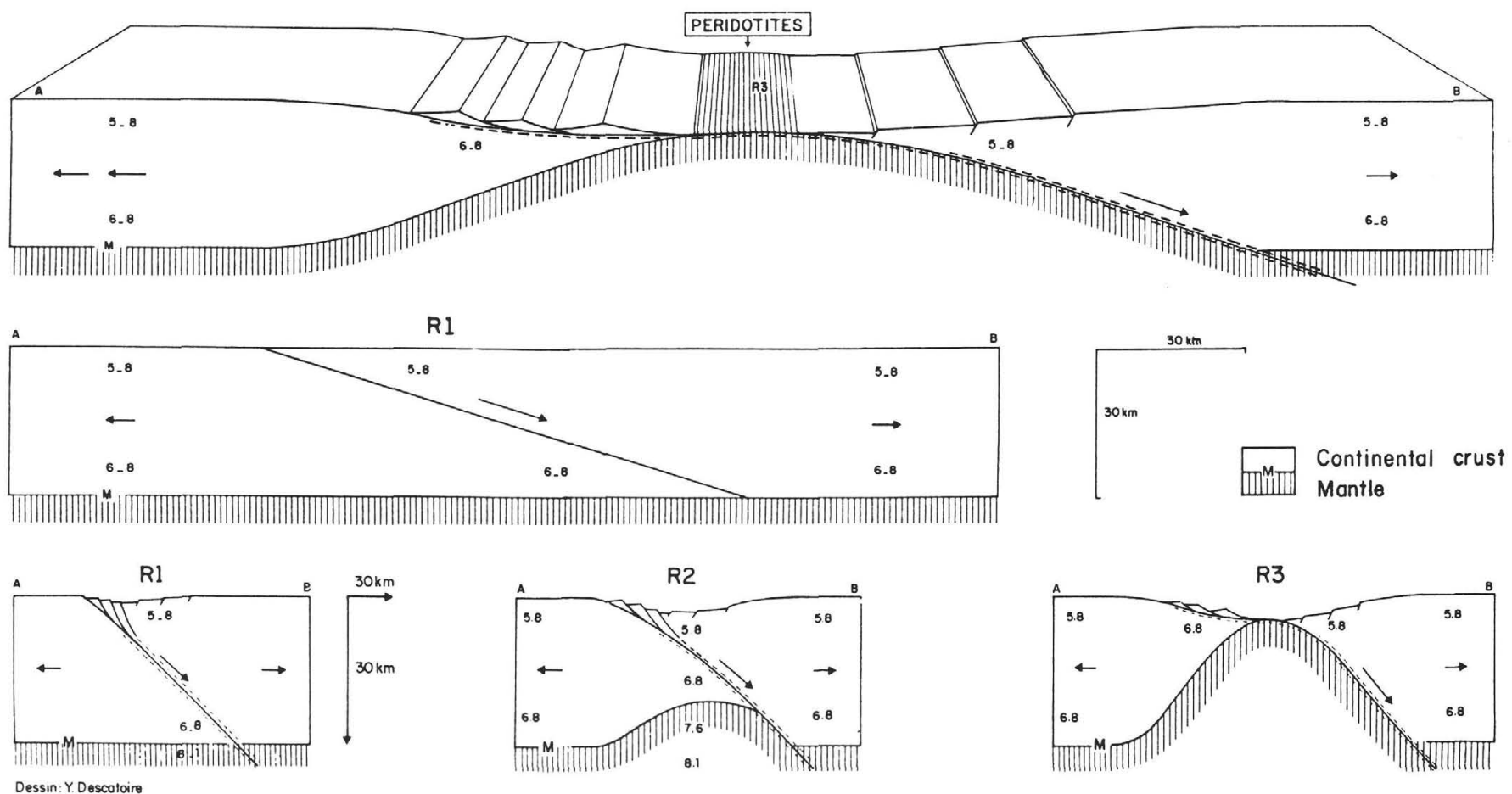

Figure 10. The low-angle normal fault model of the tectonic denudation of the upper mantle, after Boillot et al. (1986b, 1987). The upper two cross sections are without vertical exaggeration; cross sections in the bottom row have a vertical scale $\times 3$. Seismic velocities $(\mathrm{km} / \mathrm{s})$ are indicated on the cross sections. R1, R2, and R3 = successive stages of the continental rift $\mathrm{R}$, resulting in tectonic denudation of the uppermost mantle.

titude in slow-spreading ridges or oceanic rifts and a flat attitude in medium- to fast-spreading ridges (see discussion in Boudier and Nicolas, 1985; Nicolas, 1986a, 1986b).

True diapirs (with a bubble shape; Ramberg, 1967; Berner et al., 1973; Dixon, 1975) of asthenosphere that rise within the lithosphere (the rising force is the density contrast) exist at depth beneath continental rifts, as deduced from the specific textures of peridotites in alkali basalts (see discussion in Mercier, 1985). In such diapirs, the strain-stress pattern appears complex because the deformation plane trajectory is expected to be horizontal at the top of the diapir and strongly inclined at the diapir edges and foot. Also, deformation intensity is at a maximum at the edges and foot and at a minimum in the core, where isotropic conditions and leading specific textures (poikiloblastic texture; Mercier, 1985) are reached. Moreover, deformation probably occurs under high-temperature-low-stress conditions at the core of the diapir, whereas much lower temperature and higher stress conditions occur at its rims.

The physical conditions inferred for the melting and deformation (primary and mylonitic deformation) of Site 637 peridotites can be considered to indicate diapiric emplacement of some asthenospheric material at the end of stretching, just before the oceanic accretion stage (Girardeau et al., this volume). Nevertheless, the partial-melting products of the mantle rocks (basalts) are missing on the Galicia margin peridotite ridge. In our opinion, having no basalts present constitutes a serious problem for the model of vertical asthenosphere diapirism, because this model predicts basalt flow at the top of the asthenosphere bulge. This lack or disappearance of basalts on the seafloor bounding the Galicia margin is surprising and must be explained.

\section{Discussion: A Composite Model}

As a tentative explanation of the uplift of Site 637 peridotites during the rifting phase prior to the opening of the Atlantic Ocean, we have presented two models (detachment faulting and asthenosphere diapirism). Theoretically, both models account for the physical conditions required for partial melting and deformation of the drilled peridotite and for the geometry of the flow displayed by the rocks. The mylonitization experienced by the rock may develop either at the edge of an asthenosphere diapir or along a detachment fault by simple shear of the lithosphere. In fact, the petrology and the fabric of the peridotite cannot be used to discriminate between the two models. Consequently, we must look at other geological and geophysical data.

The hypothesis of low-angle, normal faulting of the continental lithosphere is supported by (1) the discrepancy between the amount of superficial distension of the margin continental basement and the amount of crustal thinning; (2) the thinning of the continental crust at the expense of its lower layer (assuming a detachment fault dipping eastward, beneath the Galicia margin and mainland); and (3) the absence of basalt on the cored peridotite ridge (the products of partial melting of the peridotite being left behind above the detachment fault). The strongest argument against the hypothesis is the large belt of ultramafic seafloor (several tens of kilometers) that has to bound the Canadian margin (the section of the lithosphere crossed by the detachment fault), if we are assuming that the peridotite represents the lower part of the lithosphere.

Conversely, the strongest evidence in support of vertical diapirism of the asthenosphere at the rift axis is the physical conditions (1) of melting (assuming that it occurred during the rifting of the margin) and (2) of the ductile deformation of the peridotite. According to our petrological study, the upwelling of the peridotite occurred in asthenospheric conditions as beneath a spreading axis. Arguments against vertical diapirism are (1) the absence of basalt on the seafloor, despite partial melting of the peridotite (which would be covered by melting products if it had ascended vertically) and (2) that this model does not consider the actual processes of crustal thinning (especially crustal stretching-thinning relations). 


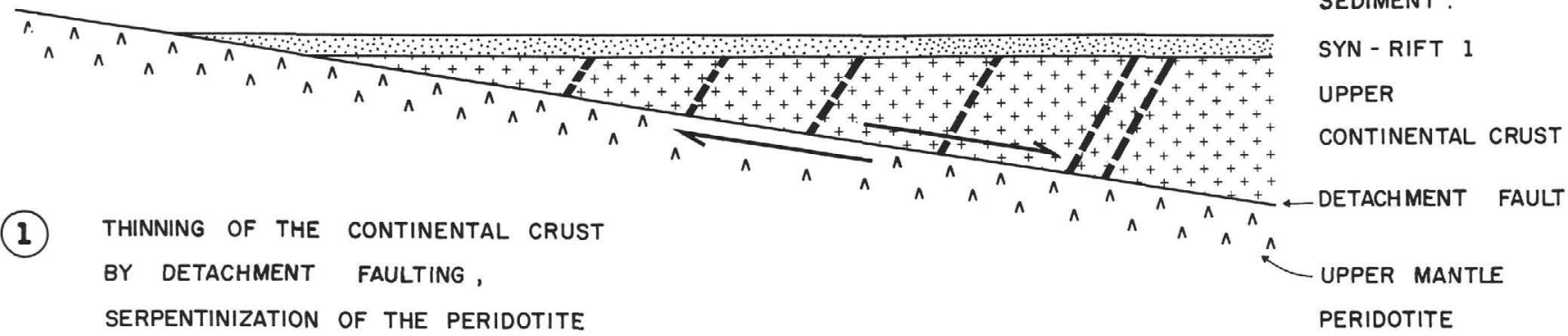

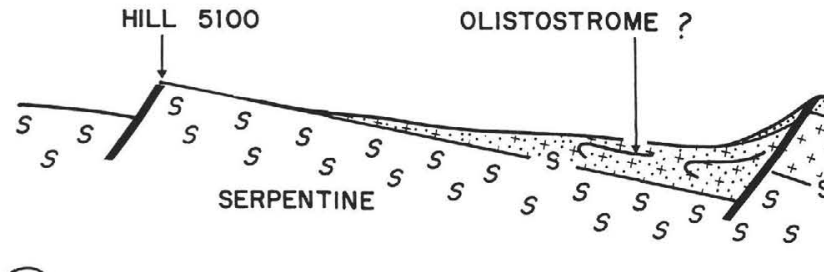

(2)

NORMAL FAULTING

TILTING OF THE BLOCKS,

ACCOMMODATED IN THE SERPENTINE LAYER

Figure 11. Kinematic interpretation of the S reflector. A. Detachment faulting, resulting in thinning of the continental crust and tectonic denudation of the upper mantle, as detailed in Figure 10. The normal faulting concurrent in the evolutionary sequence is considered remote to obtain a simplified diagram. B. Late normal faulting and tilting of the blocks, resulting in local differences in level for the S reflector with the normal fault in the plastic and mobile serpentine layer. See Figures 3 and 8 for seismic control and Figure 4 for comparison.

Are the two models antagonistic and exclusive? Uplift of the peridotite by diapirism is highly likely, according to the petrological and structural data. But on the other hand, detachment faulting accounts perfectly for the crustal thinning and stretching of the margin. Consequently, we propose a composite model, on the assumption that the main stage of asthenosphere upwelling occurred prior to the main stage of detachment faulting (Fig. 13). Asthenosphere would rise by diapirism beneath a poorly, if at all, stretched, thick continental crust (Fig. 13A), as proposed by Nicolas et al. $(1985,1987)$ and Bonatti $(1987)$ to explain the uplift of Zabargad Island peridotite. The products of the peridotite partial melting would crystallize under high pressure as gabbros and be emplaced at the top of the asthenosphere bulge, that is, at the bottom of the continental crust. At that stage, detachment faulting would either be initiated or not occur. Then, as the asthenosphere diapirism progresses, the detachment faulting beneath the Newfoundland margin (Fig. 13) could occur, which would result in tectonic denudation of the cooled peridotites that experienced low partial melting (Fig. 13B) prior to the beginning of oceanic spreading. Note that the basement of the opposite Galicia margin will include the gabbros crystallized during the initial stage (Fig. 13A). Because of isostatic readjustment during thinning of the crust, these gabbros have to be tilted landward, causing them to dip as the Moho does beneath the margin. Landward-dipping reflectors have been observed at the ocean/continent boundary of the eastern Canadian margin, which is the Galicia conjugate margin (de Voogd and Keen, 1987). Following Keen and de Voogd (1988), we suggest that these reflectors are the gabbros missing on the Galicia peridotite ridge (Fig. 13B).

\section{CONCLUSIONS}

Whatever the processes of rifting on the passive continental margin may be, the most significant result of drilling and diving on the west Galicia margin is evidence of a continuous peridotite belt bounding the thinned continental crust. The mantle rocks crop out at the ocean/continent boundary in a place occupied by the rift axis 115 or 120 m.y. ago, just before "true" seafloor spreading started between Galicia and Newfoundland. Thus, the thinning of the continental crust by horizontal stretching of the lithosphere can result, at least in some cases, in the denudation of the upper mantle. This conclusion is of great consequence in that it applies new constraints to stretching models of the lithosphere. It also provides a key to interpreting some of the ophiolitic association in fold belts formed by serpentine directly covered by sediments (Lemoine at al., 1987). These ophiolitic associations could be relicts of ultramafic seafloor settled along continental margins prior to folding, as it is presently the case for the peridotites bounding the west Galicia margin. Alternatively, the serpentine could floor narrow oceans or oceans where the spreading rate was very low. In any case, the results of investigation of the peridotite ridge of the Galicia margin open the way for further research and speculation on the rifting and/or spreading processes and on the nature of the oceanic crust.

\section{ACKNOWLEDGMENTS}

We thank B. de Voogd, K. Kimball, and A. Meyer for constructive comments on the first version of this paper. We thank also A. Nicolas and A. Mauffret for useful discussions. This work was supported by CNRS, ATP Geologie-Géophysique des Océans. Contribution no. 0433 of the Groupe d'Etudes de la Marge Continentale, Université Pierre et Marie Curie and CNRS (UA 718) and no. 1020 of the IPGP (UA 1093).

\section{REFERENCES}

Ave Lallemand, H., and Carter, N. L., 1970. Syntectonic recrystallization of olivine and modes of flow in the upper mantle. Geol. Soc. Am. Bull., 81:2203-2220.

Barbier, F., Duverge, J., and Le Pichon, X., 1986. Structure profonde de la marge nord-gascogne: implications sur le méchanisme de rifting et de formation de la marge continentale. Bull. Cent. Rech. Explor. Prod. Elf Aquitaine, 10:105-121.

Berner, H., Ramberg, H., and Stephansson, O., 1972. Diapirism in theory and experiments. Tectonophysics, 15:197-218.

Boillot, G., Auxiètre, J. L., Dunand, J. P., Dupeuble, P. A., and Mauffret, A., 1979. The northwestern Iberian margin: a Cretaceous passive margin deformed during Eocene. In Talwani, M., Hay, W., and 
Ryan, W.B.F. (Eds.), Deep Drilling Results in the Atlantic Ocean: Continental Margins and Paleoenvironment: Am. Geophys. Union, Maurice Ewing Ser., 3:138-153.

Boillot, G., Comas, M. C., Girardeau, J., Kornprobst, J., Loreau, J.-P., Malod, J., Mougenot, D., and Moullade, M., 1986a. Fonds sousmarins basaltiques et ultramafiques au pied d'une marge stable. Résultats préliminaires de la campagne Galinaute (plongées du submersible Nautile à l'ouest de l'Espagne). C. R. Acad. Sci. Ser. 2, 303:1719-1724.

Boillot, G., Grimaud, S., Mauffret, A., Mougenot, D., Mergoil-Daniel, J., Kornprobst, J., and Torrent, G., 1980. Ocean-continent boundary off the Iberian margin: a serpentinite diapir west of the Galicia bank. Earth Planet. Sci. Lett., 48:23-34.

Boillot, G., Recq, M., Winterer, E. L., Meyer, A. W., Applegate, J., Baltuck, M., Bergen, J. A., Comas, M. C., Davies, T. A., Dunham, K., Evans, C. A., Girardeau, J., Goldberg, D. G., Haggerty, J., Jansa, L. F., Johnson, J. A., Kasahara, J., Loreau J.-P., Luna-Sierra, E., Moullade, M., Ogg, J., Sarti, M., Thurow, J., and Williamson, M., 1986b. Amincissement de la croûte continentale et dénudation tectonique du manteau supérieur sous les marges stables: à la recherche d'un modèle. L'exemple de la marge continentale de la Galice. Bull. Cent. Rech. Explor. Prod. Elf Aquitaine, 10:95-104.

1987. Tectonic denudation of the upper mantle along passive margins: a model based on drilling results (ODP Leg 103, western Galicia margin, Spain). Tectonophysics, 132:335-342.

Bonatti, E., 1987. The rifting of continents. Sci. Am., 258:96-103.

Bonatti, E., Hamlyn, P., and Ottonello, G., 1981. Upper mantle beneath a young oceanic rift: peridotites from the Island of Zabargad (Red Sea). Geology, 9:474-479.

Bonatti, E., Ottonello, G., and Hamlyn, R. E., 1986. Peridotites from the Island of Zabargad (St. John), Red Sea: petrology and geochemistry. J. Geophys. Res., 91:599-631.

Boudier, F., and Nicolas, A., 1985. Harzburgite and lherzolite subtypes in ophiolitic and oceanic environments. Earth Planet. Sci. Lett., 76: 84-92.

Brun, J. P., and Choukroune, P., 1983. Normal faulting block tilting and décollement in a stretched crust. Tectonics, 2:345-556.

Brun, J. P., Choukroune, P., and Faugères, E., 1985. Les discontinuités significatives de l'amincissement crustal: application aux marges passives. Bull. Soc. Geol. Fr., 1:139-144.

de Charpal, O., Guennoc, P., Montadert, L., and Roberts, D. G., 1978. Rifting, crustal attenuation and subsidence in the Bay of Biscay. $\mathrm{Na}$ ture, 275:706-711.

Chenet, P., Montadert, L., Gairaud, H., and Roberts, D. G., 1982. Extension ratio measurements on the Galicia, Portugal, and northern Biscay continental margins: implications for evolutionary models of passive continental margins. In Watkins, J. S., and Drake, C. L. (Eds.), Studies in Continental Geology: Mem. Am. Assoc. Pet. Geol., 34:703-715.

Cordoba, D., Banda, E., and Ansorge, J., 1887. The Hercynian crust in northwest Spain: a seismic survey. Tectonophysics, 132:321-333.

Coward, M. P., 1986. Heterogenous stretching, simple shear and basin development. Earth Planet. Sci. Lett., 80:325-336.

Dixon, J. M., 1975. Finite strain and progressive in models of diapiric structures. Tectonophysics, 28:89-124.

Gibbs, A. D., 1984. Structural evolution of extensional basin margins. J. Geol. Soc. London, 141:609-620.

Grau, G., Montadert, L., Delteil, R., and Winnock, E., 1973. Structure of the European continental margin between Portugal and Ireland from seismic data. Tectonophysics, 20:319-339.

Grimaud, S., Boillot, G., Collette, B. J., Mauffret, A., Miles, P. R., and Roberts, D. B., 1982. Western extension of the Iberian-European plate boundary during the Early Cenozoic (Pyrenean) convergence: a new model. Mar. Geol., 45:63-77.

Groupe Galice (Auzende, J.-M., Jonquet, H., Olivet, J.-L., Sibuet, J.-C., Auxiètre, J. L., Boillot, G., Dunand, J. P., Mauffret, A., de Charpal, O., Apotolescu, V., and Montadert, L.), 1979. The continental margin off Galicia and Portugal: acoustical stratigraphy, dredge stratigraphy and structural evolution. In Sibuet, J.-C., Ryan, W.B.F., et al., Init. Repts. DSDP, 47, Pt. 2: Washington (U.S. Govt. Printing Office), 633-662.

Guennoc, P., Jonquet, H., and Sibuet, J.-C., 1979. Présentation d'une carte magnétique de l'Atlantique nord-est. C. R. Acad. Sci. Ser. D. 288:1011-1013.
Keen, C. E., and de Voogd, B., 1988. The continent-ocean boundary at the rifted margin off eastern Canada: new results from seismic reflections studies. Tectonics, 7:107-124.

Kent, C. E., and Gradstein, F. M., 1985. A Cretaceous and Jurassic geochronology. Geol. Soc. Am. Bull., 96:1419-1427.

Kornprobst, J., and Vielzeuf, D., 1984. Transcurrent crustal thinning: a mechanism for the uplift of deep continental crust-upper mantle associations. In Kornprobst, J. (Ed.), Kimberlites: Amsterdam (Elsevier), 347-359.

Lallemand, S., Mazé, J. P., Monti, S., and Sibuet, J.-C., 1985. Présentation d'une carte bathymétrique de l'Atlantique nord-est. $C . R$. Acad. Sci. Ser. 2, 300:145-149.

Laughton, A. S., Roberts, D. G., and Graves, R., 1975. Bathymetry of the northeast Atlantic. Mid-Atlantic Ridge to southwest Europe. Deep Sea Res. Part A, 22:792-810.

Lemoine, M., Tricard, P., and Boillot, G., 1987. Ultramafic and gabbroic ocean floor of the Ligurian Tethys (Alps, Corsica, Apennines): in search of a genetic model. Geology, 15:622-625.

Le Pichon, X., and Barbier, F., 1987. Passive margin formation by lowangle faulting within the upper crust: the northern Bay of Biscay margin. Tectonics, 6:133-150.

Le Pichon, X., and Sibuet, J.-C., 1981. Passive margins: a model of formation. J. Geophys. Res., 86:3708-3720.

Lister, G. S., Etheridge, M. A., and Symonds, P. A., 1986. Detachment faulting and the evolution of passive continental margin. Geology, $14: 246-250$.

Mauffret, A., and Montadert, L., 1987. Rift tectonics on the passive continental margin off Galicia (Spain). Mar. Pet. Geol., 4:49-69.

McKenzie, D., 1978. Some remarks on the development of sedimentary basin. Earth Planet. Sci. Lett., 40:25632.

Mercier, J.C.C., 1977. Natural peridotites: chemical and rheological heterogeneity of the upper mantle [Ph.D. thesis]. SUNY, Stony Brook. 1985. Olivine and pyroxenes. In Werk, H. (Ed.), Preferred Orientation in Deformed Metals and Rocks: An Introduction to Modern Texture Analysis: New York (Academic Press), 407-430.

Montadert, L., 1984. La marge continentale du Nord du Golfe de Gascogne et le Bassin d'Aquitaine. In Boillot, G. (Ed.), Les Marges Continentales Actuelles et Fossiles autour de la France: Paris (Masson), 83-154.

Montadert, L., de Charpal, O., Roberts, D. G., Guennoc, P., and Sibuet, J.-C., 1979. Northeast Atlantic passive continental margins: rifting and subsidence processes. In Talwani, M., Hay, W., and Ryan, W.B.F. (Eds.), Deep Drilling Results in the Atlantic Ocean: Continental Margins and Paleoenvironments: Am. Geophys. Union, Maurice Ewing Ser., 3:154-186.

Montadert, L., Roberts, D. G., et al., 1979. Init. Repts. DSDP, 48: Washington (U.S. Govt. Printing Office).

Montadert, L., Winnock, E., Delteil, J. R., and Grau, G., 1974. Continental margins of Galicia-Portugal and Bay of Biscay. In Burk, C. L., and Drake, C. L. (Eds.), The Geology of Continental Margins: Berlin (Springer Verlag), 323-342.

Nicolas, A., 1984. Lherzolites of the western Alps: a structural review. In Kornprobst, J. (Ed.), Kimberlites: Amsterdam (Elsevier), 347359.

1986a. A melt extraction model based on structural studies in mantle peridotites. J. Petrol., 27:999-1022.

1986b. Structure and petrology of peridotites: clues to their geodynamic environment. Rev. Geophys., 24:875-895.

Nicolas, A., Bouchez, J. L., Boudier, F., and Mercier, J.C.C., 1971. Textures, structures and fabrics due to solid state flow in some European Iherzolites. Tectonophysics, 12:55-86.

Nicolas, A., Boudier, F., Lyberis, N., Montigny, R., and Guennoc., P., 1985. L'Ile de Zabargad (St Jean): témoin de l'expansion précoce en Mer Rouge. C. R. Acad. Sci. Ser. 2, 30:1063-1068.

Nicolas, A., Boudier, F., and Montigny, R., 1987. Structure of Zabargad Island and early rifting of the Red Sea. J. Geophys. Res., 92:461474.

Olivet, J. L., Bonnin, J., Beuzart, P., and Auzende, J. M., 1984. Cinématique de l'Atlantique nord et central: Publ. Cent. Nat. Exploit. Oceans, 56.

Parson, M. L., Masson, D. G., Pelton, C. D., and Grant, A. C., 1985. Seismic stratigraphy and structure of the east Canadian continental margin between 41 and $52^{\circ}$ N. Can. J. Earth Sci., 22:686-703. 
Ramberg, H., 1967. Gravity, Deformation and the Earth's Crust: London (Academic Press).

Royden, L., and Keen, C. E., 1980, Rifting process and thermal evolution of the continental margin of eastern Canada determined from subsidence curves, Earth Planet. Sci. Lett., 51:343-361.

Shipboard Scientific Party, 1987a. Introduction, objectives, and principal results: Ocean Drilling Program Leg 103, west Galicia margin. In Boillot, G., Winterer, E. L., et al., Proc. ODP, Init. Repts., 103: College Station, TX (Ocean Drilling Program), 3-17. 1987b. Site 637. In Boillot, G., Winterer, E. L., et al., Proc. $O D P$, Init. Repts., 103: College Station, TX (Ocean Drilling Program), 123-219.

1987c. Site 638. In Boillot, G., Winterer, E. L., et al., Proc. ODP, Init. Repts., 103: College Station, TX (Ocean Drilling Program), 221-407.

1987d. Site 639. In Boillot, G., Winterer, E. L., et al., Proc. ODP, Init. Repts., 103: College Station, TX (Ocean Drilling Program), 409-532.

1987e. Site 640. In Boillot, G., Winterer, E. L., et al., Proc. ODP, Init. Repts., 103: College Station, TX (Ocean Drilling Prograin), 533-569.

Sibuet, J.-C., Mazé, J. P., Amortila, P., and Le Pichon, X., 1987. Physiography and structure of the western Iberian continental margin off Galicia, from Sea Beam and seismic data. In Boillot, G., Winterer, E. L., et al., Proc. ODP, Init. Repts., 103: College Station, TX (Ocean Drilling Program), 77-97.

Sibuet, J.-C., and Ryan, W.B.F., 1979. Site 398: evolution of the west Iberian passive continental margin in the framework of the early evolution of the North Atlantic Ocean. In Sibuet, J.-C., Ryan,
W.B.F., et al., Init. Repts. DSDP, 47, Pt. 2: Washington (U.S. Govt. Printing Office), 761-775.

Spencer, J. E., 1984. Role of tectonic denudation in warping and uplift of low-angle normal faults. Geology, 12:95-98.

Srivastava, S., and Tapscott, C. R., 1987. Plate kinematics of the north Atlantic. In Tucholke, B. E., and Vogt, P., (Eds.), The Geology of North America: The Western North Atlantic Region: Geol. Soc. Am., DNAG Ser., M:379-404.

Verhoef, J., Colette, B. J., Miles, P. R., Searle, R. C., Sibuet, J.-C., and Williams, C. A., 1986. Magnetic anomalies in the northeast Atlantic Ocean. Mar. Geophys. Res., 8:1-25.

Vielzeuf, D., and Kornprobst, J., 1984. Crustal splitting and the emplacement of Pyrenean lherzolites and granulites. Earth Planet Sci. Lett., 67:87-96.

de Voogd, B., and Keen, C. E., 1987. Lithoprobe east: results from reflection profiling of the continental margin: Grand Bank region. Geophys. J. R. Astron. Soc., 89:195-620.

Wernicke, B., 1981. Low-angle normal faults in the basin and range province: nappe tectonics in an extending orogen. Nature, 291:645648.

1985. Uniform-sense normal simple shear of the continenta lithosphere. Can. J. Earth Sci., 22:108-125.

Wernicke, B., and Burchfield, B. C., 1982. Modes of extensional tectonics. J. Struct. Geol., 4:105-115.

Date of initial receipt: 8 June 1987

Date of acceptance: 15 December 1987 Ms 103B/179

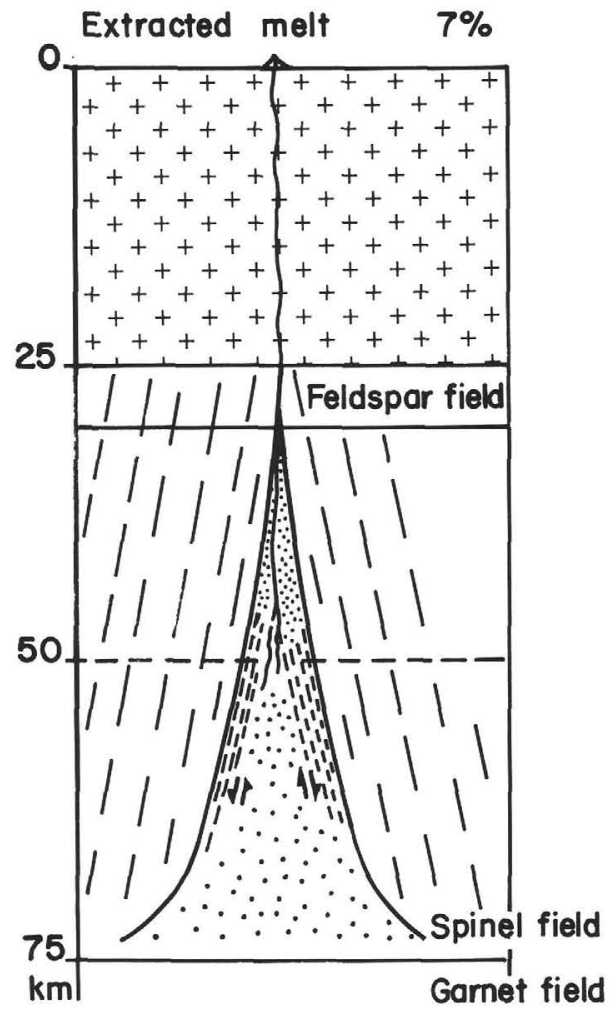

Figure 12. Sketch of asthenosphere diapirism and melt extraction asthenosphere for a continental rift before crustal thinning, after Nicolas (1986a, 1986b). Dashed lines represent the frozen asthenosphere flow; the dotted area is the asthenosphere. This situation could be the initial stage for the west Galicia margin, 140 m.y. ago. 
A

A Continental rift Detachment fault

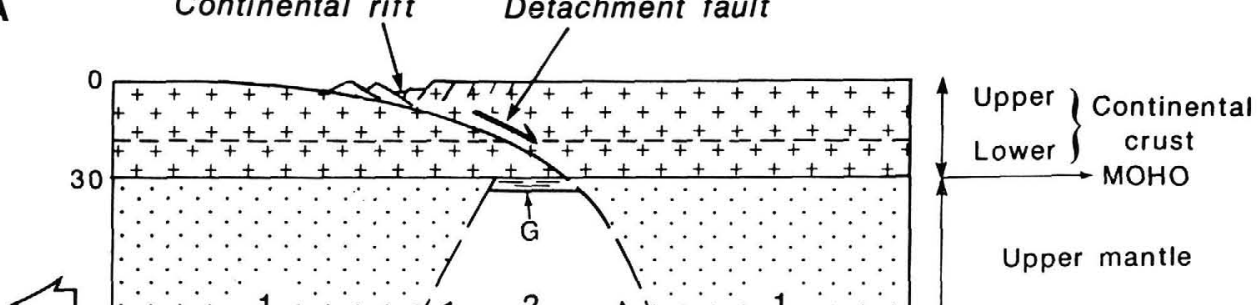

4

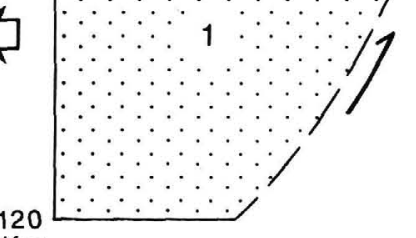

2

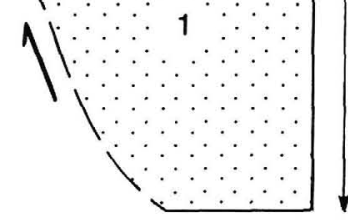

peridotite

$\mathrm{Km}$

B NEWFOUNDLAND spreading center axis

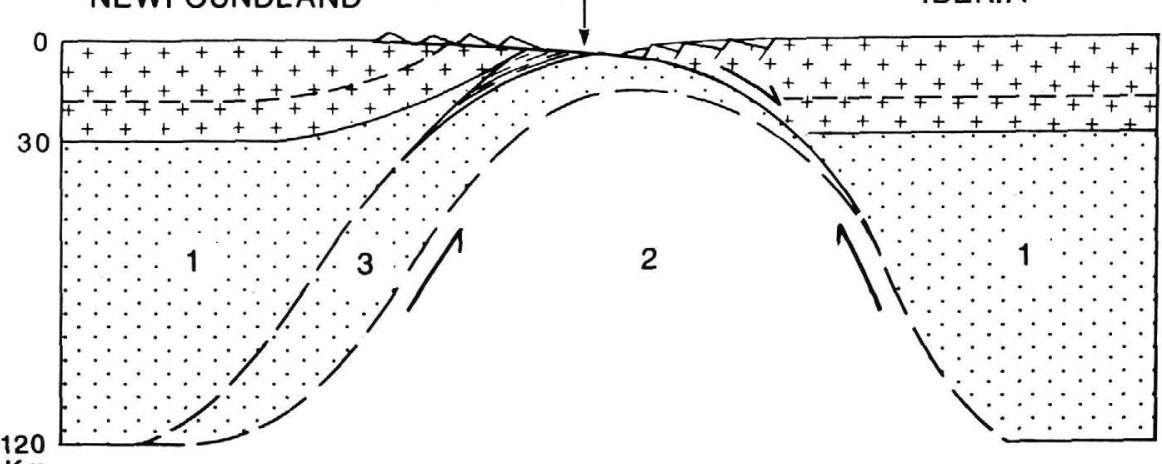

$\mathrm{Km}$

Figure 13. The composite model for the thinning of the continental crust and the emplacement of peridotite onto the seafloor along the Galicia margin (possible initial stage, see Fig. 12). A. Bulge of asthenosphere, yielding to low partial melting of the peridotite and possible crystallization of the partial-melting products as gabbro (G) at the crust/mantle boundary. This stage is derived from the models by Nicolas (1986a, 1986b), Nicolas et al. $(1985,1987)$, and Bonatti (1987). B. Tectonic denudation of gabbro along Newfoundland margin and of cooled, poorly depleted peridotite along Galicia margin. This stage of evolution is described by the model of Boillot et al. (1987) (see Fig. 10). 1 = lithosphere subcrustal peridotite; 2 = upwelling peridotite experiencing low partial melting and behaving as an asthenosphere bulge; this poorly depleted asthenospheric peridotite further accreted to the lithosphere $(=3)$. The last stage of the evolution would be the beginning of classic ocean spreading. 